\title{
Drying-Rewetting and Flooding Impact Denitrifier Activity Rather than Community Structure in a Moderately Acidic Fen
}

\author{
Katharina Palmer ${ }^{1,2}$, Julia Köpp ${ }^{3}$, Gerhard Gebauer ${ }^{3}$ and Marcus A. Horn ${ }^{1 * \dagger}$ \\ ${ }^{1}$ Department of Ecological Microbiology, University of Bayreuth, Bayreuth, Germany, ${ }^{2}$ Water Resources and Environmental \\ Engineering Research Group, University of Oulu, Oulu, Finland, ${ }^{3}$ BayCEER-Laboratory of Isotope Biogeochemistry, \\ University of Bayreuth, Bayreuth, Germany
}

\section{OPEN ACCESS}

Edited by:

Paul Bodelier,

Netherlands Institute of

Ecology-KNAW, Netherlands

Reviewed by:

Sven Marhan,

University of Hohenheim, Germany

Annelies J. Veraart,

Netherlands Institute of

Ecology-KNAW, Netherlands

*Correspondence:

Marcus A. Horn

horn@ifmb.uni-hannover.de

${ }^{\dagger}$ Present Address:

Marcus A. Horn,

Soil Microbiology, Institute of

Microbiology, Leibniz University of

Hannover, Hannover, Germany

Specialty section:

This article was submitted to

Terrestrial Microbiology,

a section of the journal

Frontiers in Microbiology

Received: 16 October 2015

Accepted: 02 May 2016

Published: 01 June 2016

Citation:

Palmer K, Köpp J, Gebauer G and Horn MA (2016) Drying-Rewetting and

Flooding Impact Denitrifier Activity Rather than Community Structure in a

Moderately Acidic Fen.

Front. Microbiol. 7:727.

doi: 10.3389/fmicb.2016.00727
Wetlands represent sources or sinks of the greenhouse gas nitrous oxide $\left(\mathrm{N}_{2} \mathrm{O}\right)$. The acidic fen Schlöppnerbrunnen emits denitrification derived $\mathrm{N}_{2} \mathrm{O}$ and is also capable of $\mathrm{N}_{2} \mathrm{O}$ consumption. Global warming is predicted to cause more extreme weather events in future years, including prolonged drought periods as well as heavy rainfall events, which may result in flooding. Thus, the effects of prolonged drought and flooding events on the abundance, community composition, and activity of fen denitrifiers were investigated in manipulation experiments. The water table in the fen was experimentally lowered for 8 weeks in 2008 and raised for 5.5 months in 2009 on three treatment plots, while three plots were left untreated and served as controls. In situ $\mathrm{N}_{2} \mathrm{O}$ fluxes were rather unaffected by the drought treatment and were marginally increased by the flooding treatment. Samples were taken before and after treatment in both years. The structural gene markers narG and nos $Z$ were used to assess possible changes in the nitrate reducer and denitrifier community in response to water table manipulations. Detected copy numbers of narG and nos $Z$ were essentially unaffected by the experimental drought and flooding. Terminal restriction fragment length polymorphism (TRFLP) patterns of narG and nos $Z$ were similar before and after experimental drought or experimental flooding, indicating a stable nitrate reducer and denitrifier community in the fen. However, certain TRFs of narG and nos $Z$ transcripts responded to experimental drought or flooding. Nitrate-dependent Michaelis-Menten kinetics were assessed in anoxic microcosms with peat samples taken before and 6 months after the onset of experimental flooding. Maximal reaction velocities $v_{\max }$ were higher after than before flooding in samples from treament but not in those from control plots taken at the same time. The ratio of $\mathrm{N}_{2} \mathrm{O}$ to $\mathrm{N}_{2} \mathrm{O}+\mathrm{N}_{2}$ was lower in soil from treatment plots after flooding than in soil from control plots, suggesting mitigation of $\mathrm{N}_{2} \mathrm{O}$ emissions by increased $\mathrm{N}_{2} \mathrm{O}$-reduction rates after flooding. $\mathrm{N}_{2} \mathrm{O}$ was consumed to subatmospheric levels in all microcosms after flooding. The collective data indicate that water table manipulations had only minor effects on in situ $\mathrm{N}_{2} \mathrm{O}$ fluxes, denitrifier abundance, and denitrifier community composition of the acidic fen, while active subpopulations of denitrifiers changed in response to water table manipulations, 
suggesting functionally redundant subpopulations occupying distinct ecological niches in the fen.

Keywords: water table manipulation, climate change, wetlands, greenhouse gases, structural (functional) genes

\section{INTRODUCTION}

Peatlands cover about $3 \%$ of the earth's surface, are particularly important in mid- and high-latitudes, and store significant amounts of carbon and nitrogen (Gorham, 1991). Peatlands are sources and potential sinks of greenhouse gases such as methane $\left(\mathrm{CH}_{4}\right)$ and nitrous oxide $\left(\mathrm{N}_{2} \mathrm{O}\right)$ (Christensen et al., 2003; Goldberg et al., 2008; Kolb and Horn, 2012). $\mathrm{N}_{2} \mathrm{O}$ is a major ozone-depleting substance and has a 300x higher global warming potential than $\mathrm{CO}_{2}$, (Ravishankara et al., 2009). $\mathrm{N}_{2} \mathrm{O}$ emissions from peatland soils are controlled by microorganisms. In water saturated systems, $\mathrm{N}_{2} \mathrm{O}$ is almost exclusively produced by denitrification [i.e., the sequential reduction of nitrate and/ or nitrite via nitric oxide (NO) to $\mathrm{N}_{2} \mathrm{O}$ and $\mathrm{N}_{2}$; Zumft, 1997]. Nitrate or nitrite are used as terminal electron acceptors by denitrifiers, and are supplied to peatlands by aerial precipitation, surface runoff, groundwater inflow, or nitrification in oxic zones (Conrad, 1996; Mosier et al., 1998; Goldberg et al., 2010; Lohila et al., 2010; Palmer et al., 2010). The extent of the oxic zone, and thus the magnitude of the nitrification process as a substrate producer for denitrification, is largely dependent on the water table level in peatlands (Lipson et al., 2012). Even though many pristine peatlands are net sources of $\mathrm{N}_{2} \mathrm{O}$, (water-saturated) peatlands can be temporary sinks for $\mathrm{N}_{2} \mathrm{O}$ when nitrate/nitrite availability is low (Goldberg et al., 2008; Lohila et al., 2010; Palmer et al., 2010; Marushchak et al., 2011; Kolb and Horn, 2012; Palmer and Horn, 2012, 2015).

Peatland ecosystems are thought to be severely affected by future climate change (Gorham, 1991; Gong et al., 2012). Climate change is associated with increasing mean annual temperatures and an increased frequency of extreme weather events like prolonged dry periods and heavy rainfalls (Hartmann et al., 2013), which have the potential to lower and raise the water tables in soils, respectively (Gong et al., 2012). Those changes in watertable height will likely affect greenhouse gas emissions from peatlands. The effect of water table fluctuations on $\mathrm{N}_{2} \mathrm{O}$ emissions from wetlands is variably affected e.g., by the amplitude, frequency and duration of the water table fluctuations (Mander et al., 2011), ranging from enhanced emissions after long-term drainage (e.g., for forestry or agriculture), moderate short-term drainage or rapid flooding of dried peat soil (Martikainen et al., 1993; Goldberg et al., 2010; Maljanen et al., 2010; Jørgensen and Elberling, 2012) to reduced $\mathrm{N}_{2} \mathrm{O}$ emissions after flooding of peat soil (McNicol and Silver, 2014). Highly fluctuating water tables and rapid switching between water table heights lead to higher cumulative $\mathrm{N}_{2} \mathrm{O}$ emissions than stable water tables in wetland soils (Dinsmore et al., 2009; Mander et al., 2011; Jørgensen and Elberling, 2012; McNicol and Silver, 2014). In the past, much more attention has been paid to the effect of long-term (e.g., in multi-year drainage or peat restoration) than of short-term changes (i.e., on the basis of several weeks or months) in water table height on $\mathrm{N}_{2} \mathrm{O}$ fluxes from peatlands.
Even fewer studies have focused on the effects of short-term intensive water table fluctuations on the denitrifier communities involved in $\mathrm{N}_{2} \mathrm{O}$ turnover in peatland soils (Kim et al., 2008). Kim et al. (2008) found a decline in nirS abundance in response to short-term drought in soil cores of bog and fen, suggesting a decline in proteobacterial nirS-hosting denitrifiers. Diversity of nirS was stable. However, effects of water table manipulations on denitrifier communities in situ are unclear to date.

Most denitrifiers are facultative aerobes and thrive under oxic as well as under anoxic conditions (Shapleigh, 2013). Indeed, oxygen rather than nitrate is the preferred electron acceptor for many denitrifiers, suggesting that oxic conditions will not impair denitrifiers and their genetic potential. Thus, we hypothesize that short-term water table fluctuations will change the denitrification activity of peat denitrifiers rather than their community composition. Thus, the aims of the present study were (i) to assess the effect of raised water tables on dentrification potentials in a model peatland, (ii) to determine the effect of lowered and raised water tables on the community composition of denitrifers, (iii) to detect possible changes in the active denitrifer communities, and (iv) to try to link the obtained results to observed in situ $\mathrm{N}_{2} \mathrm{O}$ fluxes.

\section{MATERIALS AND METHODS \\ Study Site and Experimental Setup}

The minerotrophic fen Schlöppnerbrunnen is located in the Lehstenbach catchment (Fichtelgebirge, Germany; N 50 07' 53", E $11^{\circ} 52^{\prime} 51^{\prime \prime}$ ). Please refer to Palmer et al. (2010) for a more detailed description of the sampling site. Mean air temperature was 6.9 and $6.6^{\circ} \mathrm{C}$, while annual precipitation was 957 and $972 \mathrm{~mm}$ in 2008 and 2009, respectively. Three treatment and three untreated control plots (size $7.2 \times 5 \mathrm{~m}$ ) were established on the site and water table manipulations were performed as described (Estop-Aragonés et al., 2012, 2013). In brief, treatment plots were subjected to experimental drought and flooding in the summers of 2008 and 2009, respectively. The height of the water table was measured continuously in treatment and control plots (Figure S1). Experimental drought was achieved by rain water exclusion and drainage ditches in the time period between June 10th and August 7th 2008. PlexiGlas ${ }^{\circledR}$ roofs allowing for light penetration and above ground air movement were temporarily installed during the drought period, thus minimizing potential side effects. After the experimental drought period, roofs were removed, drainage was stopped, and drought plots were rewetted with artificial rainwater $(103 \mathrm{~mm}$ within $8 \mathrm{~h})$. Experimental flooding was achieved by irrigating the treatment plots with water from the nearby creek "Lehstenbach." Creek water was spread onto the treatment plots via perforated tubes at an average rate of $70 \mathrm{~m}^{3}$ per day and plot in the time period between May 14th and October 30th 2009. Maximum temperatures of drought 
and flooding plots in $5 \mathrm{~cm}$ of depth were $\sim 1^{\circ} \mathrm{C}$ higher and $1.5^{\circ} \mathrm{C}$ lower than in control plots at the same time, respectively, indicating a minor effect of water table manipulations on the peat temperature regime (Estop-Aragonés et al., 2012).

Samples for molecular analyses were collected in both years, while samples for microcosm studies were collected in 2009 only due to the need of minimizing destructive samplings in 2008. In 2008, soil was sampled for molecular analysis before drought (June 09th) and at the end of the drought phase (July 27th). In 2009, samples were taken before flooding (i.e., before the onset of irrigation; May 11th) and after flooding (i.e., after irrigation had been discontinued; November 16th). Soil samples were taken with a peat soil corer from depth 0 to $40 \mathrm{~cm}$. Soil samples for molecular analyses were separated into four layers $(0-10,10-$ $20,20-30,30-40 \mathrm{~cm}$ ), frozen immediately in liquid nitrogen, and stored at $-80^{\circ} \mathrm{C}$ until use. Soil for microcosm studies was separated into two layers $(0-20$ and $20-40 \mathrm{~cm})$ and stored at $4{ }^{\circ} \mathrm{C}$ for max. $24 \mathrm{~h}$ prior to microcosm studies. Potential anaerobic microbial activities were significantly higher in 0-20 than 20$40 \mathrm{~cm}$ depth, and dissolved oxygen in pore water was close to air saturation deeper than $30 \mathrm{~cm}$ of depth in drought plots during water level drawdown (Wüst et al., 2009; Palmer et al., 2010; Estop-Aragonés et al., 2012). Air filled pore space was greater than $12 \%$ (up to $50 \%$ at the end of the drought period) from 0 to $20 \mathrm{~cm}$ of depth in drought plots (Estop-Aragonés et al., 2012). After the rewetting of drought plots, dissolved oxygen decreased to lower than $20 \%$ air saturation in $0-10 \mathrm{~cm}$ depth and declined to $\sim 0$ with increasing depth (Estop-Aragonés et al., 2012). In control plots, oxygen penetration was significant until $20 \mathrm{~cm}$ of depth (Estop-Aragonés et al., 2012). Thus, the results of (note: not the samples before) molecular analyses from 0 to 10 plus 10 to $20 \mathrm{~cm}$, and from 20 to 30 plus 30 to $40 \mathrm{~cm}$ were pooled.

\section{Water Table Manipulations and Effects on Biogeochemistry}

During the period of experimental drought (June 10th 2008 to August 7th 2008), water table heights ranged from -71 to $-12 \mathrm{~cm}$ and from $-90 \mathrm{~cm}$ (i.e., $90 \mathrm{~cm}$ below peat surface) to $-14 \mathrm{~cm}$ in control and treatment plots, respectively (Estop-Aragonés et al., 2012; Figure S1). Average water table heights were -26.8 and $-62.1 \mathrm{~cm}$ in control and drought plots, respectively, i.e., the water table was on average $35.4 \mathrm{~cm}$ higher in control than in treatment plots. Air filled pore space in $5 \mathrm{~cm}$ depth approximated $30 \%$ in control plots and $50 \%$ in drought plots. Water oxygen saturation approximated $0-1$ and $80 \%$ in $30 \mathrm{~cm}$ depth of control and drought plots, respectively. Such strong lowering of the water table (i) increased dissolved oxygen levels close to saturation in more than $30 \mathrm{~cm}$ depth and (ii) significantly decreased concentrations of dissolved inorganic carbon in drought treatment relative to control plots (Estop-Aragonés et al., 2013). Nitrate concentrations were $0.02-0.15 \mathrm{mM}$ in the pore water during the experimental period (Estop-Aragonés et al., 2013).

During flooding (May 14th 2009 to October 30th 2009), water table heights ranged from -49 to $1.6 \mathrm{~cm}$ and from -18 to $4.9 \mathrm{~cm}$ in control and treatment plots, respectively (Estop-Aragonés et al., 2012; Figure S1). Average water table heights were -15.4 and $-0.7 \mathrm{~cm}$ in control and treatment plots, respectively, i.e., the water table was on average $14.7 \mathrm{~cm}$ higher in treatment than in control plots. Flooding (i) decreased dissolved oxygen (near $0 \mu \mathrm{mol} / \mathrm{l}$ in the final flooding phase), dissolved inorganic carbon and nitrate concentrations, and (ii) increased nitrate dependent electron turnover, acetate, and hydrogen concentrations relative to control plots (Estop-Aragonés et al., 2013).

\section{Assessment of In situ $\mathbf{N}_{\mathbf{2}} \mathrm{O}$-Fluxes}

In situ $\mathrm{N}_{2} \mathrm{O}$-fluxes were measured by the closed chamber technique from late May to early November 2008 and from midApril to mid-October 2009. The measurements were conducted as described earlier (Goldberg et al., 2010). In brief, three collars (1.15 l volume) were installed on each plot, and $\mathrm{N}_{2} \mathrm{O}$ fluxes were measured in regular intervals (2-4 and 1-2 times per month in 2008 and 2009, respectively). For the measurements, chambers of $4 \mathrm{l}$ volume were placed on top of the collars, and the $\mathrm{N}_{2} \mathrm{O}$ concentration in the chamber headspace was measured after 0 , $8,16,24$, and 32 min using a photoacoustic infrared gas analyzer (Multigas Monitor 1312, INNOVA, Denmark). $\mathrm{N}_{2} \mathrm{O}$ flux rates were calculated based on the linear increase or decrease in $\mathrm{N}_{2} \mathrm{O}$ concentration in the chamber headspace.

\section{Assessment of Denitrification Potentials in Soil Microcosms}

Denitrification potentials of fen soil (0-20 and 20-40 cm) at its in situ $\mathrm{pH}$ were assessed in nitrate-supplemented anoxic microcosms as described earlier (Palmer et al., 2010). In brief, one volume of fen soil was diluted with three volumes of water in 125-ml infusion flasks, the flasks were sealed with butyl-rubber stoppers and the airspace was purged with argon to achieve anoxic conditions. The flasks were preincubated at $15^{\circ} \mathrm{C}$ for $\sim 16 \mathrm{~h}$ to reduce intially present nitrate. After preincubation, $\mathrm{NaNO}_{3}$ was added to the flasks $(0-100 \mu \mathrm{M}$ nitrate). Flasks were incubated for up to $12 \mathrm{~h}$ in the dark at $15^{\circ} \mathrm{C}$, and $\mathrm{N}_{2} \mathrm{O}$ headspace concentrations in each flask were quantified at three timepoints using a Hewlett-Packard 5980 series II gas chromatograph equipped with an electron capture detector, and a Porapak Q-80/100 (Supelco, Bellefonte, PA) column (length, 4 $\mathrm{m}$; inner diameter, $3.2 \mathrm{~mm}$ ) with $\mathrm{Ar}-\mathrm{CH} 4$ (95:5) as the carrier gas. Acetylene inhibition was used to distinguish between $\mathrm{N}_{2} \mathrm{O}$ production and total denitrification and to estimate the ratio of $\mathrm{N}_{2} \mathrm{O}$ to $\left(\mathrm{N}_{2} \mathrm{O}+\mathrm{N}_{2}\right)$ as described earlier (Yoshinari and Knowles, 1976; Palmer et al., 2010). $\mathrm{N}_{2} \mathrm{O}$ production rates and apparent kinetic parameters [Michaelis-Menten constants $\left(K_{M}\right)$, maximum reaction velocitites $\left(v_{\max }\right), v_{\max } / K_{M}$ ] were determined as described (Palmer et al., 2010).

\section{Extraction of Nucleic Acids and Reverse Transcription}

Nucleic acids from all sampled soil layers taken in 2008 were extracted using a bead-beating protocol (Griffiths et al., 2000) followed by separation of DNA and RNA using the Qiagen RNA/DNA Mini Kit (QIAGEN GmbH, Hilden, Germany) according to the manufacturer's instructions. Nucleic acids from all sampled soil layers taken in 2009 were extracted using 
a similar bead-beating protocol with the exception that an additional aluminum precipitation was performed prior to bead beating to remove humic acids (Persoh et al., 2008; Palmer et al., 2012). Although cell lysis procedures that are regarded as critical for the DNA/RNA extraction bias were essentially identical, comparison of community structure between the two years might be biased. Identical DNA/RNA extraction procedures were applied within each year, thus allowing for a meaningful analysis of the effect of water table manipulations on microbial community structure. Reverse transcription of extracted RNA into cDNA was conducted using the SuperScript VILO cDNA Synthesis Kit (Invitrogen, Karlsruhe, Germany) according to the manufacturer's protocol.

\section{Quantitative PCR}

Quantitative kinetic real-time PCRs (qPCRs) of narG [narG1960f (TAY GTS GGS CAR GAR AA)/narG2650r (TTY TCR TAC CAB GTB GC); Philippot et al., 2002], nosZ [nosZF (CGC TGT TCI TCG ACA GYC AG)/nosZR (ATG TGC AKI GCR TGG CAG AA); Rich et al., 2003], and bacterial 16S rRNA genes [Eub341F (CCT ACG GGA GGC AGC AG)/Eub534R (ATT ACC GCG GCT GCT GG); Muyzer et al., 1993] from DNA samples were performed in three technical replicates per plot, sampling time point and soil depth as described (Zaprasis et al., 2010; Palmer et al., 2012). nar $G$ and nos $Z$ amplified from cDNA obtained from the same fen samples during triplicate qPCRs yielded multiple bands on agarose gels and multiple melting points during melting curve analyses. Thus, nar $G$ and nos $Z$ expression was not assessed. However, the bands with the correct size were excised from agarose gels and used for TRFLP analyses.

Obtained gene copy numbers were corrected for inhibition by spiking environmental DNA extracts with standard DNA as described earlier (Zaprasis et al., 2010; Palmer et al., 2012). Obtained inhibition factors ranged from 0.2-1.0, 0.1-1.0, and 0.1-1.0 for narG, nos $Z$, and 16S rRNA genes, respectively. Copy numbers of narG, nos $Z$, and 16S rRNA genes were compared between treatments and time points by Tukey's HSD test in IBM SPSS 22 after testing for normal distribution in R.

\section{Terminal Restriction Fragment Length Polymorphism}

Triplicate qPCR reactions of narG and nos $Z$ amplified from DNA or cDNA were pooled and gel purified using the Montage Gel Extraction Kit (Millipore Corporation, Bedford, MA, USA) prior to TRFLP analysis. The purified PCR products were digested with Mung Bean nuclease (New England Biolabs, Frankfurt am Main, Germany) to remove single-stranded DNA and reduce the probability of pseudo-terminal restriction fragments (Egert and Friedrich, 2003). The digested DNA was purified using the Millipore Multiscreen 96-well-Filtration System (Millipore Corporation, Bedford, MA, USA). narG and nos $Z$ PCR products were digested with the restriction enzymes CfoI and Fnu4HI (New England Biolabs, Frankfurt am Main, Germany), respectively. Polyacrylamide gel electrophoresis was performed as described previously (Palmer et al., 2010). Terminal restriction fragment (TRF) tables (i.e., relative fluorescence of TRFs per sample) were imported into Qiime 1.9 (Caporaso et al., 2010). Statistical differences between years, nucleic acid type and treatment were tested using the Qiime script compare_categories.py with the Adonis, anosim, mrpp, and permanova algorithms (for further details consult qiime.org). Results of the individual tests were compared. As obtained $P$ value estimations calculated by the different algorithms and the derived conclusions were similar, only $P$-values derived from Adonis are reported. Operational taxonomic units (OTUs as indicated by TRFs) that were differentially expressed between treatments and/or time points were identified using the Qiime script differential_otus.py. In silico digests of narG and nos $Z$ obtained in an earlier study (Palmer et al., 2010) were used to identify TRFs. However, not all TRFs clearly affiliated with a taxon or sequencing based OTU of Palmer et al. (2010). Such TRFs were not linked to phylogeny.

\section{RESULTS}

\section{Effect of Watertable Manipulations on Fen $\mathrm{N}_{2} \mathrm{O}$ Fluxes}

$\mathrm{N}_{2} \mathrm{O}$ fluxes from Schlöppnerbrunnen fen were variable (Figure 1). In 2008 (drought experiment), mean $\mathrm{N}_{2} \mathrm{O}$ fluxes fluctuated between $-0.4 \mu \mathrm{mol}^{*} \mathrm{~h}^{-1 *} \mathrm{~m}^{-2}$ (net $\mathrm{N}_{2} \mathrm{O}$ uptake) and $1.2 \mu \mathrm{mol}^{*} \mathrm{~h}^{-1 *} \mathrm{~m}^{-2}$ (net $\mathrm{N}_{2} \mathrm{O}$ emission). Differences between drought and control plots were marginal and were detected after the rewetting had occurred (Figure 1A). Cumulative $\mathrm{N}_{2} \mathrm{O}$ fluxes were positive in 2008, i.e., the fen was a net source of $\mathrm{N}_{2} \mathrm{O}$ in both drought and control plots (Figure 1B). In 2009 (flooding experiment), mean $\mathrm{N}_{2} \mathrm{O}$ fluxes ranged from $-0.4 \mu \mathrm{mol}^{*} \mathrm{~h}^{-1 *} \mathrm{~m}^{-2}$ (net $\mathrm{N}_{2} \mathrm{O}$ uptake) to $0.4 \mu \mathrm{mol}^{*} \mathrm{~h}^{-1 *} \mathrm{~m}^{-2}$ (net $\mathrm{N}_{2} \mathrm{O}$ emission). Differences between treatment and control plots were marginal in both years, indicating that $\mathrm{N}_{2} \mathrm{O}$ fluxes were essentially unaffected by the experimental drying or flooding (Figure 1A). In 2009, cumulative $\mathrm{N}_{2} \mathrm{O}$ fluxes were negative in both plot types, indicating (i) net $\mathrm{N}_{2} \mathrm{O}$ uptake in both flooding and control plots and (ii) differences between the years 2008 and 2009 (Figure 1B).

\section{Effect of Watertable Manipulations on Copy Numbers of narG, nosZ and $16 S$ rRNA Genes}

Experimental drought successfully changed water levels and soil biogeochemistry relative to control plots as did experimental flooding (Estop-Aragonés et al., 2012; Figure S1; please refer to data from our colleagues presented in the Materials and Methods section for further details on the effect of water table manipulations on biogeochemistry). Inhibtion-corrected $16 \mathrm{~S}$ rRNA gene copy numbers were averaged for depths of 0-20 and 20-40 cm, for different plot types, treatments, and time points. Averaged copy numbers ranged from $(7.8 \pm 3.0) \times 10^{4}$ to $(4.1$ $\pm 1.2) \times 10^{5}$ per ng DNA (Figures $2 \mathrm{~A}-\mathrm{D}$ ). $16 \mathrm{~S}$ rRNA gene copy numbers from both plot types and at all sampling time points were similar $(P>0.1)$. Inhibtion-corrected copy numbers of narG and nosZ amplified from extracted DNA ranged from 0.4 to $12 \%$ and from 0.01 to $0.25 \%$ of bacterial $16 \mathrm{~S}$ rRNA gene copy numbers, respectively (Figures $2 \mathbf{E}-\mathbf{L}$ ). The following effects 


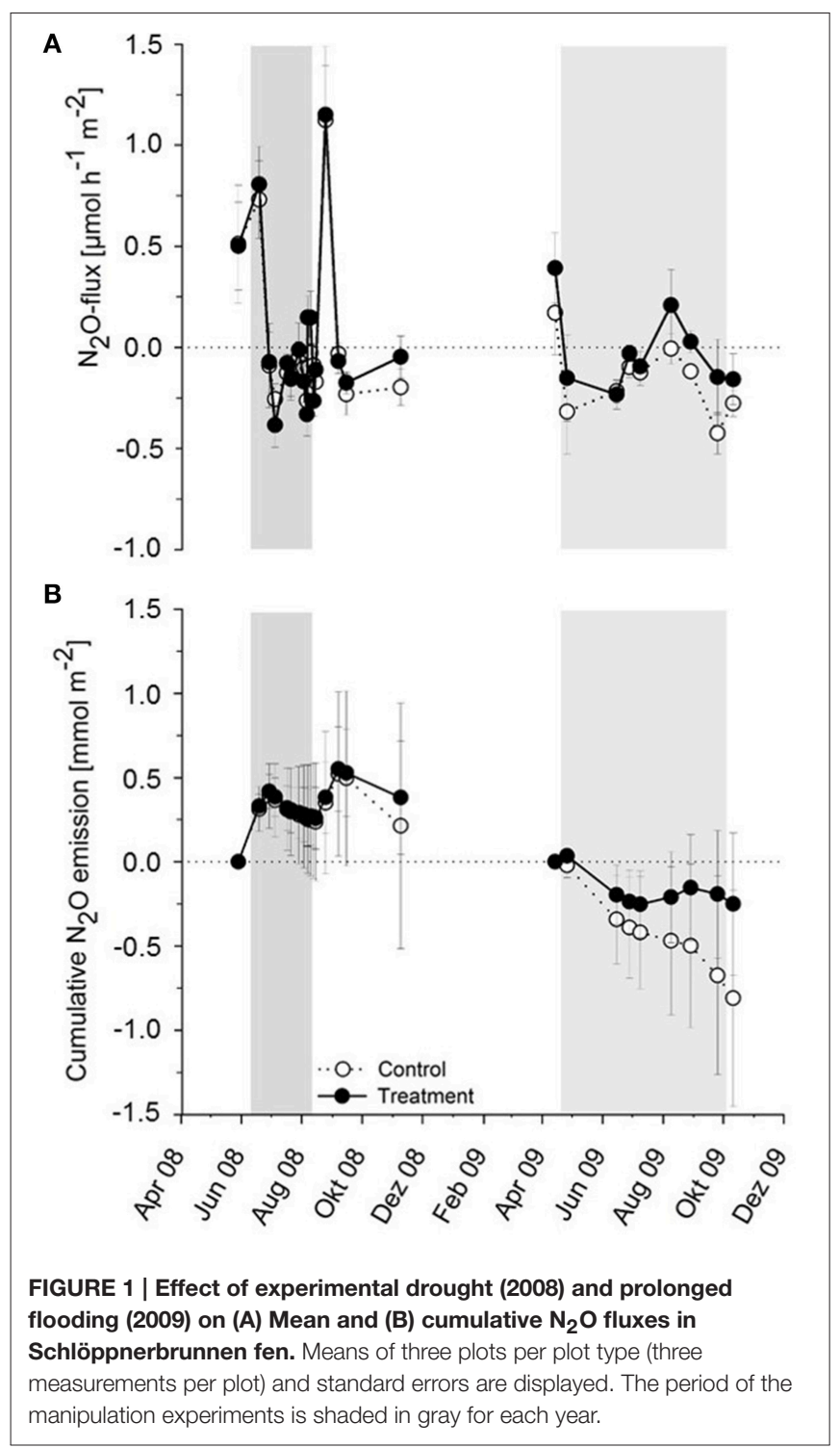

reflect tendencies rather than significant differences: In drought plots, relative abundances of nar $G$ and nos $Z$ were similar $(P$ $=0.9)$ and $3 x$ higher $(P=0.3)$, respectively, after than before drought in $0-20 \mathrm{~cm}$ peat soil, while relative abundances of both genes were similar before and after drought in $20-40 \mathrm{~cm}$ soil (narG: $P=0.7$, nosZ: $P=0.9$; Figures 2E-F,I-K). When the same time points were compared, relative abundances of narG and nos $Z$ from control plots were $2 \mathrm{x}$ lower $(P=0.4)$ and similar $(P=0.99)$, respectively, in $0-20 \mathrm{~cm}$ peat soil, and similar $(P=$ $0.99)$ and $2.5 \mathrm{x}$ lower $(P=0.8)$, respectively, in $20-40 \mathrm{~cm}$ peat soil (Figures 2E,F,I,K, respectively).

Relative abundances of nar $G$ were marginally lower after than before flooding in treatment plots in both depths $(P \geq 0.9)$, while relative abundances in control plots were about $3 \mathrm{x}$ lower $(P=0.1)$ in $0-20 \mathrm{~cm}$ peat soil when the same time points were compared (Figures 2G,H). Relative abundances of nos $Z$ were similar at the after and before flooding time points in treatment plots and control plots at the same time in $0-20 \mathrm{~cm}$ peat soil
$(P \geq 0.9)$, and marginally lower after flooding of treatment plots in $20-40 \mathrm{~cm}$ peat soil from control plots $(P=0.7$; Figures $2 \mathbf{K}, \mathbf{L})$. nar $G$ was on average $12 \mathrm{x}$ to $240 \mathrm{x}$ more abundant than nos $Z$ (Figures 2M-P). The ratio of nos $Z$ to nar $G$ was marginally higher in treatment than in control plots at both sampling time points during the drought experiment in $0-20 \mathrm{~cm}$ peat soil $(P \geq 0.7)$, and no effect of the drought treatment on nos $Z$ to nar $G$ ratios was observed (Figure $2 \mathrm{M}$ ). In $20-40 \mathrm{~cm}$ peat soil the ratio was higher before than after drought in treatment plots $(P=0.2$; Figure $2 \mathrm{~N})$. During the flooding experiment, a minor increase in the ratio of nos $Z$ to narG in treatment plots was observed after relative to before flooding in $0-20 \mathrm{~cm}(P=0.7)$ but not in $20-40 \mathrm{~cm}$ peat soil $(P=0.99$; Figures 2O,P).

\section{Effect of Watertable Manipulations on Community Composition of narG Genes}

Principal Coordinate Analysis of narG TRFLP patterns obtained from DNA samples indicative of the genetic potential for dissimilatory nitrate reduction revealed that the detected narG community composition was similar at all time points, as DNA samples clustered closely together in the PCoA plot (Figures 3A,B). This was observed in both depths, even though the clustering was slightly more pronounced in $0-20 \mathrm{~cm}$ depth (Figure 3A). Up to 9 and 13 major TRFs of narG were detected in DNA samples from both depths in 2008 and 2009, respectively, and the relative abundances of the individual TRFs were similar in treatment and control plots at all sampling time points. Detected TRFs were indicative of uncultured soil and sediment organisms related to Deinococcus-Thermus sp. of FEN CLUSTER 7, Actinobacteria-related uncultured soil bacteria of FEN CLUSTER 6, and uncultured Proteobacteria of FEN CLUSTERs 1-5 (Palmer et al., 2010) (Figures S2A,B,E,F). No statistically significant differences were detected between the treatments and time points $(P>0.2)$.

\section{Effect of Watertable Manipulations on Community Composition of narG \\ Transcripts}

Control plot samples obtained before and after treatments clustered more closely together than treatment plot samples based on TRFLP patterns of narG amplified from cDNA indicative of active nitrate reducers (Figures 3A,B). In 2008, when the drought experiment was performed, cDNA TRFLP patterns of narG differed already before drought in 0-20 and $20-40 \mathrm{~cm}$ peat soil (Figures 3A,B). The relative abundances of the two most abundant TRFs (23 and $57 \mathrm{bp}$ ) were similar in control plots in both soil layers $(P>0.9)$, while their relative abundances differed or tended to differ in treatment plots before and after drought $(P=0.01$ and $P=0.35$ for 23 and 57 bp TRF, respectively, in $0-20 \mathrm{~cm}$ soil; $P=0.04$ for both 23 and $57 \mathrm{bp}$ TRF in 20 to $40 \mathrm{~cm}$ soil; Figures S2C,D). This indicates that the activity of the groups behind those TRFs, i.e., Deinococcus-Thermus and Actinobacteria related uncultured fen nitrate reducers, is strongly affected by the experimental drought conditions (Figures S2C,D). 


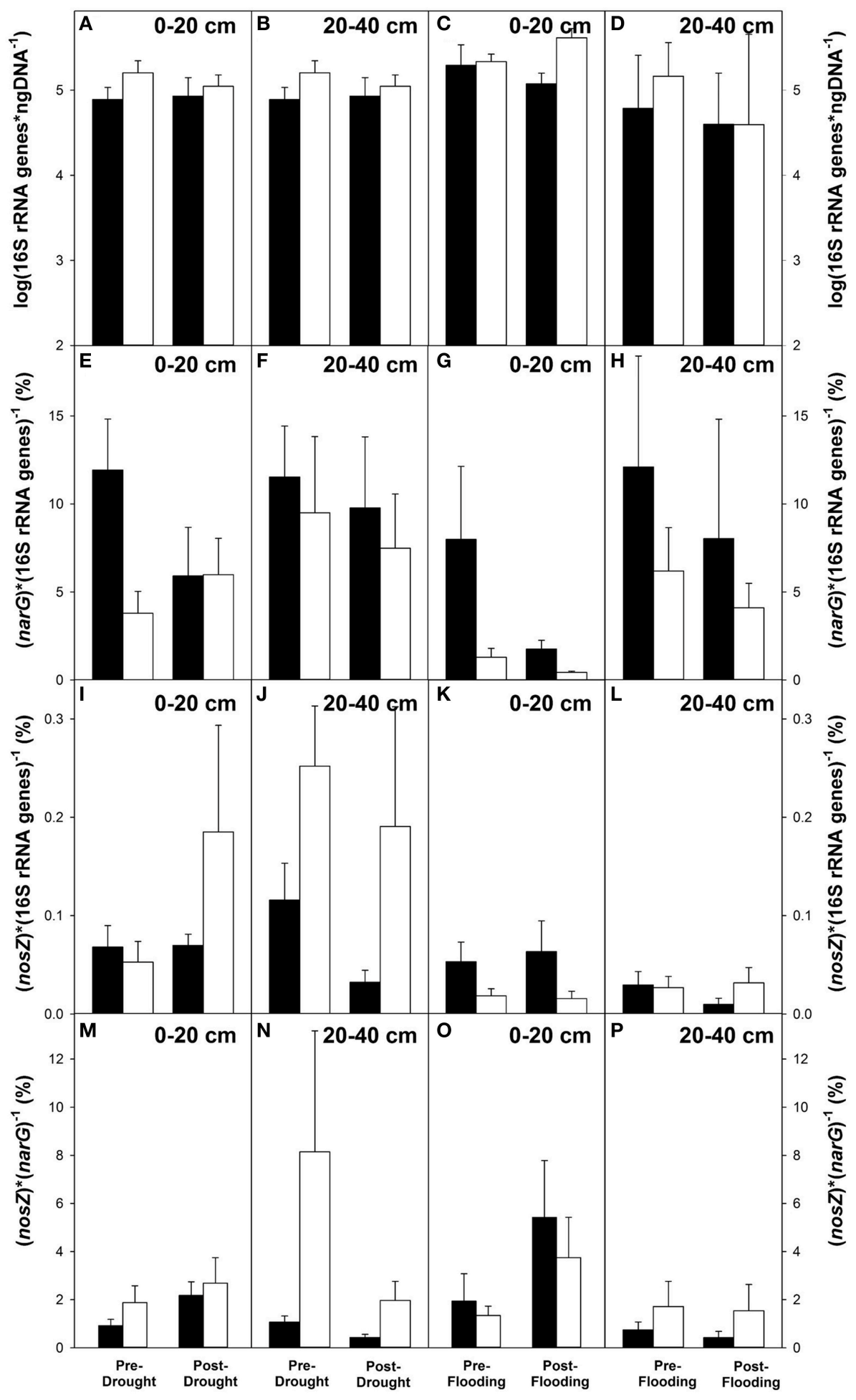

FIGURE 2 | Effect of experimental drought (left) and prolonged flooding (right) on 16S rRNA gene copy numbers (A-D), relative abundances of narG $(\mathrm{E}-\mathrm{H})$, and nosZ (I-L) as well as on the ratio of $\operatorname{nos} Z$ to $\operatorname{nar} \mathbf{G}(\mathbf{M}-\mathrm{P})$ in $\mathbf{0 - 2 0}$ and $\mathbf{2 0 - 4 0} \mathrm{cm}$ fen soil. Black bars represent control plots, white bars represent treatment plots. Mean values from triplicate analyses of all plots of one plot type and depth $0-20$ or $20-40 \mathrm{~cm}$ were calculated and are displayed with error bars. Pre-drought samples were taken on June 09th 2008, post-drought samples were taken on July 27th 2008. Pre-flooding samples were taken on May 11th 2009, post-flooding samples were taken on November 16th 2009. 


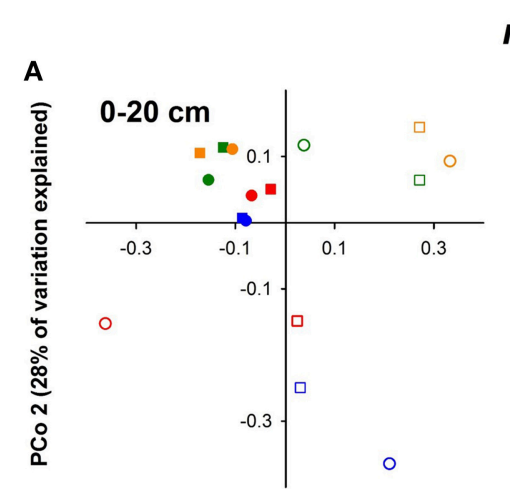

PCo 1 (44\% of variation explained)

\section{narG}

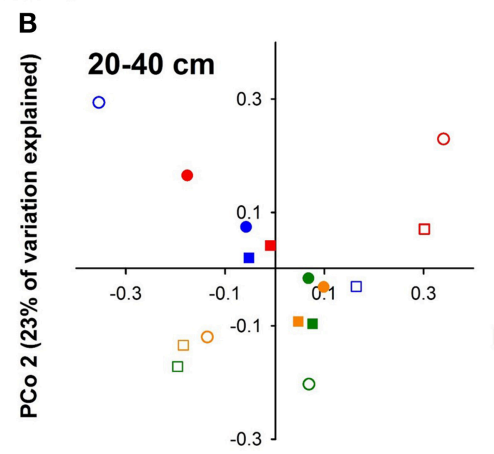

PCo 1 (39\% of variation explained)

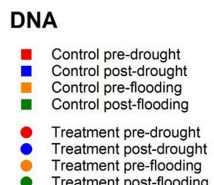

cDNA

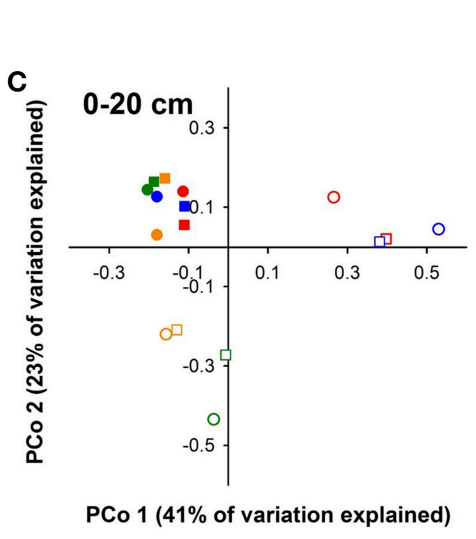

\section{nosZ}

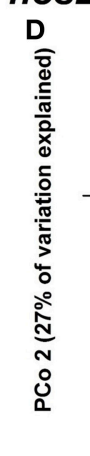

Control pre-drought

Control pre-drought
Cost-drought
Control pre-flooding

Control pre-flooding
$\square \quad$ Control post-flooding

- Treatment pre-drought

Treatment post-drought

O Treatment pre-flooding

PCo 1 (41\% of variation explained)

FIGURE 3 | Effect of artificial drought and prolonged flooding on the community composition of narG (A,B) and nosZ (C,D) in DNA and cDNA samples from fen soil from 0 to $20 \mathrm{~cm}(\mathbf{A}, \mathbf{C})$ and 20 to $\mathbf{4 0} \mathrm{cm}(\mathbf{B}, \mathbf{D})$ depth. Principal coordinate analysis was conducted in Qiime using the average relative abundances of TRFs per plottype and time point as input. Pre-drought samples were taken on June 09th 2008, post-drought samples were taken on July 27th 2008. Pre-flooding samples were taken on May 11th 2009, post-flooding samples were taken on November 16th 2009.

In 2009 when the flooding experiment was performed, cDNA TRFLP patterns of narG from control plots clustered together in the PCoA plots (Figures 3A,B). The samples from control and flooding plots taken before the flooding treatment also clustered together, indicating that the active communities were rather similar in control and treatment plots before the onset of flooding. The samples from treatment plots after treatment clustered separately in the PCoA plots, suggesting an effect of flooding on active narG expressing microbes (Figures 3A,B). Marginal differences in the relative abundance of TRFs indicative of Deinococcus-Thermus and Actinobacteria related uncultured fen nitrate reducers suggest that those groups responded to flooding in upper peat soil (Figure S2G).

\section{Effect of Watertable Manipulations on Community Composition of nos $Z$ Genes}

TRFLP patterns of nos $Z$ amplified from DNA were similar in 2008 (drought) and 2009 (flooding) and in both control and treatment plots $(P>0.2$; Figures 3C,D $)$. The five most prominent TRFs were indicative of uncultured soil organisms related to Bradyrhizobiaceae of FEN CLUSTER 1 and Rhodospirillaceae of FEN CLUSTERS 3-5 within the Alphaproteobacteria (Palmer et al., 2010) (Figures S3A,B,E,F).

\section{Effect of Watertable Manipulations on Community Composition of nosZ Transcripts}

TRFLP patterns of nos $Z$ obtained from cDNA differed from TRFLP patterns obtained from DNA in both years $(P=$ 0.001; Figures 3C,D). The TRFs that were most prominent in DNA samples accounted only for $22-52$ and $38-90 \%$ of the TRFs in cDNA samples in 2008 and 2009, respectively. In 2008, samples from control plots were rather similar in 0 to $20 \mathrm{~cm}$ depth at both sampling timepoints, while there were differences between samples taken before and after drought from treatment plots (Figure 3C). In 20 to $40 \mathrm{~cm}$ depth, samples from treatment plots taken before and after drought and those of control plots taken at the same time clustered together, and samples taken after drought were different from 
the samples taken before drought as well as from each other (Figure 3D).

Significant differences between treatments and sampling time points were not detected $(P>0.12$ in both soil layers) based on the overall TRFLP patterns obtained from cDNA samples in 2008 when the drought experiment was performed. Even though the overall community strucure was rather similar, 11 TRFs were expressed differentially in different plots or time points (Table 1; Figure S3). Those TRFs were indicative of uncultured Bradyrhizobiaceae and Rhodospirillaceae (Figure S3). Thus, data suggests that experimental drought affected activities of certain uncultured fen denitrifiers of the Alphaproteobacteria.

In 2009, when the flooding experiment was performed, samples taken before flooding of treatment plots from control and treatment plots clustered together in the PCoA plots in $0-20 \mathrm{~cm}$ depth, while they scattered in $20-40 \mathrm{~cm}$ depth (Figures 3C,D). Statistically, the overall TRFLP patterns were rather similar in both treaments and at both sampling time points in the upper layer $(P=0.3)$, indicating a minor effect of flooding on the active denitrifier community in the upper peat soil. On the contrary, the overall TRFLP patterns in the lower peat soil differed significantly between the plottypes and time points $(P=0.02)$. Seven TRFs were expressed differentially in different plots or time points (Table 2; Figure S3). The data suggests that activities of uncultered Bradyrhizobia-like denitrifiers were impaired by experimental flooding.

\section{Effect of Experimental Flooding on Denitrification Potentials}

Fen soil from both soil layers sampled before and after flooding of treatment plots from control and treatment plots produced $\mathrm{N}_{2} \mathrm{O}$ in anoxic microcosms. $\mathrm{N}_{2} \mathrm{O}$ production was minimal in all unsupplemented microcosms (Figure $\mathbf{S 4}$ ). $\mathrm{N}_{2} \mathrm{O}$ production was stimulated without apparent delay in microcosms supplemented with up to $100 \mu \mathrm{M}$ nitrate (Figure S4). Observed $\mathrm{N}_{2} \mathrm{O}$ prodcution was always higher in the presence than in the absence of acetylene, indicating that part of the $\mathrm{N}_{2} \mathrm{O}$ was further reduced to $\mathrm{N}_{2}$ in the absence of acetylene. Initial nitrate-dependent $\mathrm{N}_{2} \mathrm{O}$ production rates of fen soil microcosms amended with acetylene followed apparent Michaelis-Menten kinetics with soil from all soil layers and sampling time points (Figure S5). Apparent maximal reaction velocities $\left(v_{\max , a p p}\right)$ ranged from 7 to $68 \mathrm{nmol}$ $\mathrm{h}^{-1} \mathrm{~g}_{\mathrm{dw}}^{-1}$ and were generally higher in $0-20 \mathrm{~cm}$ than in $20-40$ $\mathrm{cm}$ soil $(P \leq 0.05$; Figures 4A,B). Apparent Michaelis-Menten constants $K_{M, a p p}$ ranged from 8 to $45 \mu \mathrm{M}$ nitrate, but there was no statistically significant difference between the two soil layers $\left(P \geq 0.1\right.$; Figures 4C,D). $v_{\text {max } \text {, app }}$ was significantly higher in treatment (i.e., flooded) plots after than before flooding in 20$40 \mathrm{~cm}$ soil $(p<0.001)$, while it was similar at both time points in control plots and in $0-20 \mathrm{~cm}$ soil from treatment plots $(p$ $\geq 0.18$; Figures $4 \mathrm{~A}, \mathbf{B}) . K_{M}$ was significantly higher after than before flooding in $0-20 \mathrm{~cm}$ soil from treatment plots, $(p=0.08)$, while there were no significant differences between $K_{M}$ in $0-20$ $\mathrm{cm}$ soil from control plots and in $20-40 \mathrm{~cm}$ soil from control
TABLE 1 | Important nosZ cDNA TRFs responding to the drought treatment.

\begin{tabular}{|c|c|c|c|c|c|c|}
\hline & & & \multicolumn{2}{|c|}{ Drought treatment } & \multicolumn{2}{|c|}{ Control } \\
\hline & & & Pre- & Post- & Pre- & Post- \\
\hline \multirow{18}{*}{$\begin{array}{l}\text { Drought } \\
\text { treatment }\end{array}$} & Pre- & 0-20 & $x$ & & $80 \uparrow^{*}$ & n.a. \\
\hline & & & & & $390 \uparrow^{* * *}$ & \\
\hline & & & & & $700 \downarrow$ *** & \\
\hline & & $20-40$ & $x$ & $80 \uparrow^{\star \star \star}$ & $103 \downarrow^{\star \star \star}$ & n.a. \\
\hline & & & & $103 \downarrow^{* * *}$ & $149 \uparrow^{* * *}$ & \\
\hline & & & & $118 \uparrow^{* * *}$ & $165 \uparrow \uparrow^{* \star}$ & \\
\hline & & & & $135 \uparrow^{* \star \star}$ & $419 \uparrow^{* \star}$ & \\
\hline & & & & $149 \uparrow{ }^{* *}$ & & \\
\hline & & & & $165 \uparrow * * *$ & & \\
\hline & & & & $298 \downarrow$ * & & \\
\hline & Post- & $0-20$ & & $x$ & n.a. & \\
\hline & & $20-40$ & $80 \downarrow^{* \star *}$ & $x$ & n.a. & $103 \downarrow^{* *}$ \\
\hline & & & $103 \uparrow * * *$ & & & $118 \downarrow^{* * *}$ \\
\hline & & & $118 \downarrow^{* * \star}$ & & & \\
\hline & & & $135 \downarrow$ ฟ** & & & \\
\hline & & & $149 \downarrow^{\star \star}$ & & & \\
\hline & & & $165 \downarrow$ *** & & & \\
\hline & & & $298 \uparrow *$ & & & \\
\hline \multirow[t]{9}{*}{ Control } & Pre- & $0-20$ & $80 \downarrow$ * & n.a. & $x$ & $80 \downarrow$ * \\
\hline & & & $390 \downarrow^{* * \star}$ & & & $390 \downarrow^{\star \star \star}$ \\
\hline & & & $700 \uparrow * * \star$ & & & $700 \uparrow^{* * *}$ \\
\hline & & $20-40$ & & n.a. & $x$ & \\
\hline & Post- & $0-20$ & n.a. & & $80 \uparrow^{*}$ & $x$ \\
\hline & & & & & $390 \uparrow{ }^{* * *}$ & \\
\hline & & & & & $700 \downarrow^{* * *}$ & \\
\hline & & $20-40$ & n.a. & 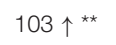 & & $x$ \\
\hline & & & & $118 \uparrow^{* * \star}$ & & \\
\hline
\end{tabular}

Arrows indicate higher or lower relative abundances of TRFs when conditions are compared from left to right. ${ }^{\star} P<0.10 ;{ }^{\star \star} P<0.05$; ${ }^{\star \star \star} P<0.01$. Empty fields indicate that no differentially expressed TRFs were detected in that comparison. n.a., not analyzed.

and treatment plot at different sampling time points $(p \geq 0.2$; Figures 4C,D).

The ratio of $\mathrm{N}_{2} \mathrm{O}$ to $\left(\mathrm{N}_{2} \mathrm{O}+\mathrm{N}_{2}\right)$ ranged from 1.9 to $79 \%$ and from 38 to $99 \%$ for all supplied nitrate concentrations in microcosms with $0-20$ and $20-40 \mathrm{~cm}$ fen soil, respectively. The average ratio of $\mathrm{N}_{2} \mathrm{O}$ to $\left(\mathrm{N}_{2} \mathrm{O}+\mathrm{N}_{2}\right)$ was 37 and $70 \%$ in $0-20$ and $20-40 \mathrm{~cm}$ fen soil, indicating that more than half of the $\mathrm{N}_{2} \mathrm{O}$ produced from nitrate was further reduced to $\mathrm{N}_{2}$ in the upper soil layer (Figures $4 \mathrm{G}, \mathrm{H}) \cdot \mathrm{N}_{2} \mathrm{O}$ to $\left(\mathrm{N}_{2} \mathrm{O}+\mathrm{N}_{2}\right)$ ratios were similar in control plots before and after flooding of treatment plots $(p \geq 0.13)$. This was observed for both sampled soil layers. On the contrary, $\mathrm{N}_{2} \mathrm{O}$ to $\left(\mathrm{N}_{2} \mathrm{O}+\mathrm{N}_{2}\right)$ ratios were significantly lower in $0-20 \mathrm{~cm}$ fen soil after than before flooding from treatment plots or than in the samples taken after flooding of treatment plots from the control plots ( $p=0.01$ and $p<0.001$, respectively). Thus, the results of the microcosm experiments indicate that prolonged flooding enhanced capacities for denitrification as well as $\mathrm{N}_{2} \mathrm{O}$ production concomittant to $\mathrm{N}_{2} \mathrm{O}$ reduction to $\mathrm{N}_{2}$. 
TABLE 2 | Important nosZ cDNA TRFs responding to the flooding treatment.

\begin{tabular}{|c|c|c|c|c|c|c|}
\hline & & & \multicolumn{2}{|c|}{ Flooding Treatment } & \multicolumn{2}{|c|}{ Control } \\
\hline & & $20-40$ & $x$ & $165 \downarrow$ ** & $\begin{array}{l}118 \uparrow \text { * } \\
309 \downarrow \text { * } \\
700 \downarrow \text { * }\end{array}$ & n.a. \\
\hline \multirow[t]{2}{*}{ Control } & Pre- & $0-20$ & & n.a. & $x$ & $90 \downarrow$ * \\
\hline & & $20-40$ & $\begin{array}{l}118 \downarrow^{*} \\
309 \uparrow^{*} \\
700 \uparrow \text { * }\end{array}$ & n.a. & $x$ & \\
\hline
\end{tabular}

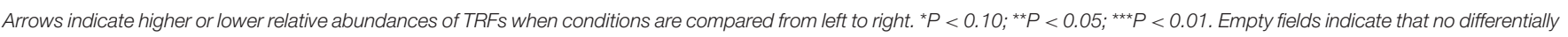
expressed TRFs were detected in that comparison. n.a., not analyzed.
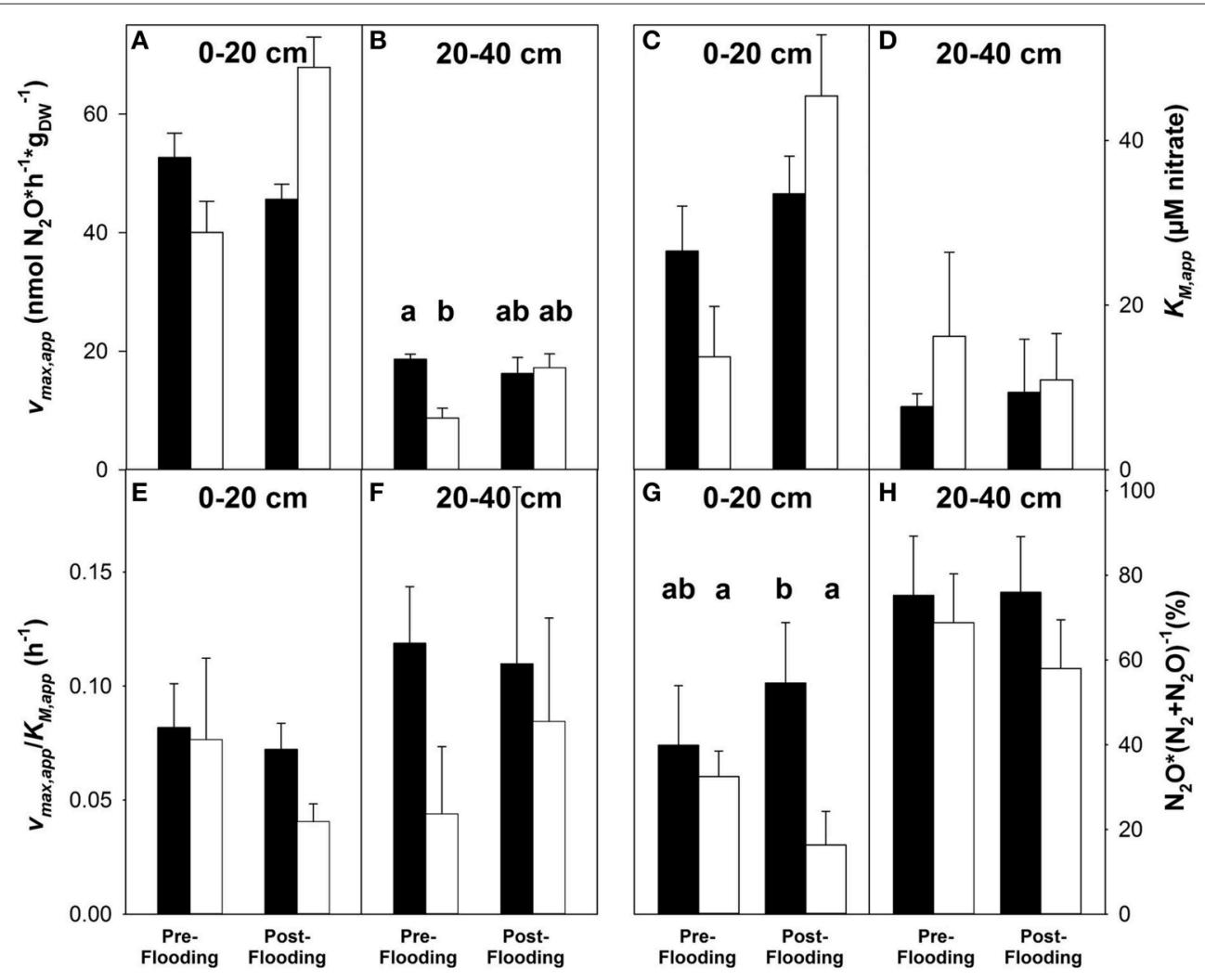

FIGURE 4 | Effect of prolonged flooding on denitrification potentials in fen soil. Effect on apparent maximal reaction velocities $\left(V_{\text {max }}\right.$,app) (A,B), apparent Michaelis-Menten constants $\left(K_{M, a p p}\right)(\mathbf{C}, \mathbf{D}), v_{\max \text {,app }} / K_{M, a p p}(\mathbf{E}, \mathbf{F})$, and $\mathrm{N}_{2} \mathrm{O}$ to $\left(\mathrm{N}_{2} \mathrm{O}+\mathrm{N}_{2}\right)$ ratios $(\mathbf{G}, \mathbf{H})$ in $0-20$ and $20-40 \mathrm{~cm}$ fen soil. Values are obtained from apparent Michaelis-Menten kinetics based on mean values and standard errors of 3 replicate measurements (see Figure S5). Black bars represent control plots, white bars represent treatment plots. Siginificantly differing values are indicated by different lower-case letters. Pre-flooding samples were taken on May 11 th 2009 , post-flooding samples were taken on November 16th 2009. 


\section{DISCUSSION}

\section{Impacts of Extreme Weather Events/Short-Term Water Table Fluctuations on Fen Processes and $\mathrm{N}_{2} \mathrm{O}$ Source and Sink Strength}

The present study extends existing data on the effects of water table manipulations obtained from peatlands by providing insights into process-associated microbial communities (Martikainen et al., 1993; Silvola et al., 1996; Reiche et al., 2009; Goldberg et al., 2010; Maljanen et al., 2010; Elberling et al., 2011; Estop-Aragonés et al., 2013). Incubation studies indicated higher denitrification potentials but reduced $\mathrm{N}_{2} \mathrm{O}$ to $\left(\mathrm{N}_{2} \mathrm{O}+\mathrm{N}_{2}\right)$ ratios after prolonged flooding (Figure 4). In situ $\mathrm{N}_{2} \mathrm{O}$ fluxes from flooded and from control plots differed marginally (Figure 1). Thus, the data indicates that the stimulation of denitrification-derived $\mathrm{N}_{2} \mathrm{O}$ production was essentially mitigated by improved $\mathrm{N}_{2} \mathrm{O}$ reduction capacities. In a recent ${ }^{15} \mathrm{~N}$-tracer study, lower $\mathrm{N}_{2} \mathrm{O}$ to $\left(\mathrm{N}_{2} \mathrm{O}+\mathrm{N}_{2}\right)$ ratios were reported under constantly flooded conditions than under fluctuating water tables in a transition bog, supporting the view that complete denitrification is stimulated in flooded peatlands (Tauchnitz et al., 2015). Similar findings were obtained with fresh water marsh, where $\mathrm{N}_{2} \mathrm{O}$ emissions are minimal when the water table is above the peat surface (Yang et al., 2013). Thus, the depletion of nitrate after prolonged flooding coupled with low $\mathrm{N}_{2} \mathrm{O}$ to $\left(\mathrm{N}_{2} \mathrm{O}+\mathrm{N}_{2}\right)$ ratios might prevent higher $\mathrm{N}_{2} \mathrm{O}$ emissions from fen soil, while maintaining its capacity for nitrogen removal.

In Schlöppnerbrunnen fen, $\mathrm{N}_{2} \mathrm{O}$ emissions increased upon rewetting after moderate water table drawdown in 2007 (Goldberg et al., 2010). This was consistent with the literature indicating that rewetting peat sites coincides with high nitrate turnover (Russow et al., 2013). However, $\mathrm{N}_{2} \mathrm{O}$ emissions were rather stable during the more severe water table drawdown in 2008 (Figure 1). During severe water table drawdown, alternative electron acceptors can accumulate (Reiche et al., 2009; EstopAragonés et al., 2013) and accumulated nitrate is expected to stimulate denitrification derived $\mathrm{N}_{2} \mathrm{O}$ emissions upon rewetting. However, nitrate accumulation in drought plots was not dramatically higher than in control plots (Estop-Aragonés et al., 2013). Most denitrifiers are heterotrophs depending on organic electron donors (Shapleigh, 2013). Dissolved organic carbon concentrations strongly decreased in response to strong water table drawdown, suggesting that limitations of easily available electron donors did not allow for a stimulation of denitrification and associated $\mathrm{N}_{2} \mathrm{O}$ production upon rewetting relative to control plots (Estop-Aragonés et al., 2013).

\section{Regulators of Denitrification and $\mathrm{N}_{2} \mathrm{O}$ Turnover during Short-Term Water Table Fluctuations}

In situ denitrifier activity is dependent on a variety of environmental factors such as soil temperature, water table height, and availability of $\mathrm{N}$-oxides. Higher soil temperatures as well as higher soil moisture content generally promote denitrification (Stres et al., 2008; Palmer et al., 2010). Thus, highest sink functions of wetlands for nitrate and $\mathrm{N}_{2} \mathrm{O}$ are observed in summer (Jørgensen and Elberling, 2012). Oxygen availability in peat is mainly controlled by watertable height (Estop-Aragonés et al., 2012). Elevated dissolved oxygen concentrations in the pore water are well known to suppress synthesis of denitrification associated reductases (Tiedje et al., 1982; Shapleigh, 2013). Redox potential changes rather than water content itself impact $\mathrm{N}_{2} \mathrm{O}$ emissions (Liu et al., 2012). However, activities of nitrate, nitrite, nitric oxide, and nitrous oxide reductases display different sensitivities toward oxygen inhibition in model organsims such as Paracoccus denitrificans and Pseudomonas fluorescens (Davies et al., 1989; McKenney et al., 1994). Nitrate reduction is generally the least oxygen sensitive step. Nitrite, $\mathrm{NO}$, and $\mathrm{N}_{2} \mathrm{O}$ reductions are each increasingly sensitive to oxygen inhibition. Indeed, only the $\mathrm{N}_{2} \mathrm{O}$ reductase is directly inhibited by oxygen (Zumft, 1997). Thus, increased oxygen concentrations due to lowered water tables explain initial increases in $\mathrm{N}_{2} \mathrm{O}$ production observed after moderate water table drawdown in Schlöppnerbrunnen fen and suggest a contribution of denitrifiers to increased $\mathrm{N}_{2} \mathrm{O}$ emissions due to impaired $\mathrm{N}_{2} \mathrm{O}$ reduction (Goldberg et al., 2010). $\delta^{15} \mathrm{~N}$ and $\delta^{18} \mathrm{O}$ values of $\mathrm{N}_{2} \mathrm{O}$ suggest a minor contribution, if any, by nitrification (Goldberg et al., 2010). The observed $\mathrm{N}_{2} \mathrm{O}$ consumption of Schlöppnerbrunnen fen when water tables were lowered either naturally in control or experimentally in treatment plots (Figure 1) remains a phenomenon to date that necessitates more research in the future.

Heightened and lowered water tables decrease and increase peat temperature, respectively. In Schlöppnerbrunnen fen, maximal temperatures were $1.5^{\circ} \mathrm{C}$ lower in flooded than in control plots and about $1^{\circ} \mathrm{C}$ higher in drought than in control plots (Estop-Aragonés et al., 2012). Given the daily temperature amplitude of $17^{\circ} \mathrm{C}$ in control plots in $5 \mathrm{~cm}$ of depth, such differences appear to be minimal (EstopAragonés et al., 2012). Those moderate changes in temperature have the potential to affect denitrifier activities, but do not necessarily change denitrifier community composition (Stres et al., 2008). Indeed, denitrifier community composition in Schlöppnerbrunnen fen remained similar at all time points of the manipulation experiments (Figure 3; Figures S2, S3). During periods of drought, enhanced rates of nitrification are feasible due to elevated oxygen availability (Fromin et al., 2010). In Schlöppnerbrunnen fen soil, nitrate concentrations in the pore water increased upon moderate water level draw down up to $500 \mu \mathrm{M}$ and decreased after rewetting (Herrmann et al., 2012). Although nitrate was not significantly increased due to strong water level drawdown, concentrations of other terminal electron acceptors such as $\mathrm{Fe}^{3+}$ and sulfate increased during drying and decreased during rewetting, suggesting a buffering capacity for high redox potentials in the fen (Estop-Aragonés et al., 2013). Such a buffering capacity together with carbon limitation might have prevented a major stimulation of denitrification after rewetting.

During flooding, constant inputs of nitrate and sulfate raised their concentrations in the peat to $\sim 40$ and 100 $\mu \mathrm{M}$, respectively (Estop-Aragonés et al., 2013). The constant 
supply of nitrate in low concentrations might lead to growth and activation of fen denitrifiers, which are often $\mathrm{N}$-limited, and increased nitrate supply might lead to increased $\mathrm{N}_{2} \mathrm{O}$ emissions (Novak et al., 2015; Palmer and Horn, 2015). Along these lines, denitrification capacities of Schlöppnerbrunnen fen were higher after than before flooding in treatment plots (Figures 4A-F). Potential $\mathrm{N}_{2} \mathrm{O}$ to $\left(\mathrm{N}_{2} \mathrm{O}+\mathrm{N}_{2}\right)$ ratios (Figures $4 \mathrm{G}, \mathrm{H}$ ) tended to be lower after than before flooding, while the abundance of denitrification associated genes remained rather unaffected or tended to decrease (Figure 2). Model denitrifiers such as $P$. denitrificans and $P$. fluorescens are capable of minimizing $\mathrm{N}_{2} \mathrm{O}$-release during complete denitrification under stable anoxic conditions by a stable expression of denitrification associated reductases (McKenney et al., 1994; Baumann et al., 1996). Such data suggest that the nitrate input during flooding did not allow for massive growth of denitrifiers, and that the prevalent denitrifier community is regulated in a way that the conversion of $\mathrm{N}_{2} \mathrm{O}$ to $\mathrm{N}_{2}$ in situ was efficient.

Water table manipulation studies in wetland soils indicate that the effect of short-term water table fluctuations on denitrifier abundance is variable, ranging from no effect to decreased or increased abundances (Kim et al., 2008; Song et al., 2010). Differences in denitrifier activity are observed after short-term water table manipulations in many wetland systems (Kim et al., 2008; Song et al., 2010). In Schlöppnerbrunnen fen, the relative abundance of detected nar $G$ was rather unaffected by the drought and flooding treatments (Figures 2E-H), while the relative abundance of detected nos $Z$ was higher after drought in upper fen soil (Figure 2I). Song et al. (2010) concluded that short-term water table variations impact denitrifier activity rather than denitrifier community structure. Similar effects have been observed for methanogenic communities: While increased substrate availability increases methanogenic activity, the community composition of methanogens is rather unaffected by anthropogenic disturbances (Basiliko et al., 2013). Thus, the observed changes in denitrification potentials and $\mathrm{N}_{2} \mathrm{O}$ emission in Schlöppnerbrunnen fen appear to be caused by changes in denitrifier activity rather than by changes in denitrifier community size.

\section{Fen Denitrifiers Are Resistant to Climate Change Induced Short-Term Water Table Fluctuations and Are Capable to Adapt Their Activity to Changing Redox Conditions}

Denitrifier community composition is rather unaffected by water table fluctuations in many soils (Stres et al., 2008; Song et al., 2010). Certain microbial communities are resistant to environmental stress, such as water table fluctuations, varying temperatures or freeze-thaw events (Griffiths and Philippot, 2013). Denitrifier communities are also rather stable to water table fluctuations in other wetland soils such as in Ohio wetlands, saltmarshes or wetland ponds (Fromin et al., 2010; Song et al., 2010; McKew et al., 2011). Indeed, narG and nos $Z$ copy numbers were only marginally affected by the water table manipulations in Schlöppnerbrunnen fen (Figures 2E-L), indicating that facultative fen denitrifiers are able to cope with changing water tables and the resulting changes in oxygen supply. Moreover, DNA-based TRFLP analyses indicate a stable denitrifier community composition (Figure 3), i.e., resistance to water table changes is similar in most groups of fen denitrifiers. Earlier studies with Schlöppnerbrunnen fen soil indicate the presence of nitrate reducers including denitrifiers related to Deinococcus-Thermus, Actinobacteria as well as Alpha- and Beta-Proteobacteria (Palmer et al., 2010). Also the present study detected TRFs indicating the presence of such groups on both gene and transcript level (Figures S2, S3). Thus, based on transcript level TRFLP analysis, Deinococcus-Thermus related microbes, Proteobacteria as well as Actinobacteria were active in Schlöppnerbrunnen fen under variable environmental conditions. Deinococcus Thermus related microbes represent a deep-branching group that are widespread in extreme environments and resistant to environmental stress (da Costa et al., 2006; Theodorakopoulos et al., 2013). Proteobacteria are found in most soil ecosystems and under a variety of environmental conditions due to their versatile metabolic capabilities (Dworkin et al., 2006). Actinobacteria are likewise common to many soils, frequently occur in more extreme habitats, and show high tolerance to environmental stress (Zenova et al., 2011). Many Actinobacteria possess a truncated denitrification pathway, and $\mathrm{NO}$ or $\mathrm{N}_{2} \mathrm{O}$ are often end products of Actinobacterial denitrification (Shapleigh, 2013). Schlöppnerbrunnen fen emits up to 1 $\mu \mathrm{mol}$ NO $\mathrm{m}^{-2} \mathrm{~h}^{-1}$, demonstrating significant production and stability of $\mathrm{NO}$ to act as biological signal molecule (Goldberg et al., 2010). Less than $1 \mathrm{nM}$ concentrations of $\mathrm{NO}$ suffice to induce norBC expression and $5 \mathrm{nM}$ of $\mathrm{NO}$ result in maximal expression of norBC as well as nirs in Pseudomonas stutzeri (Vollack and Zumft, 2001). Thus, the NO produced in peatlands (eventually by incomplete denitrifiers like Actinobacteria) might act as an activator for the denitrifying microbial community in peatland soils by inducing the expression of denitrification genes (i.e., those of detected Proteobacteria).

The versatility of such peatland denitrifiers likely contributed to the observed stability of the denitrifier community. The stability of the Schlöppnerbrunnen fen denitrifier community was corroborated by the absence of significant seasonal variations in control plots (Figure 3). Boreal lake sediments likewise host a rather stable denitrifier community throughout most sampling times during a year (Saarenheimo et al., 2015). However, such findings are in contrast to other studies of agricultural soils, drained peatlands and intertidal wetland ecosystems where season significantly impacted denitrifier community composition (Bremer et al., 2007; Marhan et al., 2011; Andert et al., 2012; Hu et al., 2014; Wang et al., 2014). During such studies a developing plant community, seasonally changes of environmental parameters such as $\mathrm{pH}$, and sampling times that covered the whole year including winter contributed to the observed seasonal changes in denitrifier community. During our study, sampling was restricted to the time periods 
from June until August (experimental drought) and from May to November (experimental flooding) and established plant communities were rather stable. Minor community changes might have escaped detection by TRFLP analysis and few species sensitive to water table manipulations might have been replaced by others yielding a similar TRF. Other factors such as nutrient availability might affect the resistance of the microbial community (Royer-Tardif et al., 2010; Liu et al., 2012). Fluctuating water tables and thus redox conditions occur frequently in Schlöppnerbrunnen fen soil, thus an adaptation and hence stability of microbial communities toward redox fluctuations and changing environmental conditions is likely. Indeed, laboratory studies on soil microbes lend support for such a conclusion (Pett-Ridge and Firestone, 2005).

Although denitrifier community structure was stable and the effect of water table manipulations on in situ $\mathrm{N}_{2} \mathrm{O}$ fluxes was low, water table manipulations affected potential activities and active denitrifiers (Figures 2, 3). Microcosm experiments with Schlöppnerbrunnen fen soil indicate increased $v_{\max }$ after flooding as well as decreased $\mathrm{N}_{2} \mathrm{O}$ to $\left(\mathrm{N}_{2} \mathrm{O}+\mathrm{N}_{2}\right)$ ratios (Figure 4), and CDNA-based TRFLP analyses of narG and nos $Z$ indicate differences in the active denitrifier community at different water table regimes (Figure 3). Short-term water table fluctuations affect denitrifier activity (Fromin et al., 2010; Song et al., 2010). Denitrifier activities do not always correlate with denitrifier community structure (Andert et al., 2012). Thus, the observed stability of the fen denitrifier community composition during the vegetation period and short-term water table fluctuations might be an interesting feature that might be more common than previously thought. Observed differences in $\mathrm{N}_{2} \mathrm{O}$ emission are likely caused by changes in substrate availability and denitrifier activity rather than by changes in community composition.

\section{CONCLUSIONS AND LIMITATIONS}

Denitrifier communities are diverse, the denitrification pathway is modular, and the knowledge on existing forms of $\mathrm{N}$-oxide respiring enzymes is growing constantly. Recently, atypical nos $Z$ belonging to the clade II have been described that occur in microbes lacking modules of the denitrification pathway and those atypical nos $Z$ can account for more than half of the nos $Z$ in soil (Jones et al., 2013; Orellana et al., 2014). Organisms hosting clade II nos $Z$ can be denitrifiers or non-denitrifiers. Many non-denitrifying $\mathrm{N}_{2} \mathrm{O}$-reducers are obligate anaerobes rather than facultative aerobes, suggesting that they have a higher sensitivity toward redox fluctuations than denitrifiers. However, their importance in peatlands is unclear to date, and thus their role has to be further clarified in future studies. The present study focused on denitrifers, and the molecular analyses were conducted with primers targeting clade I nos $Z$ of denitrifiers. Due to selectivities of primers, microbial abundance and diversity might be underestimated. However, even though the present study captures only part of the genetic denitrifier diversity, trends observed for detected genes and transcripts are valid, and the collective data of the study indicate (i) rather stable in situ $\mathrm{N}_{2} \mathrm{O}$ fluxes during drought and flooding experiments, (ii) increased potential activity of fen denitrifiers as well as a higher percentage of complete denitrification after prolonged flooding, (iii) a stable denitrifier community in Schlöppnerbrunnen fen soil that is resistant to short-term water table fluctuations, (iv) a potential of the core denitrifier community to react to fluctuating water tables by differential activation, and (v) the ability of fen denitrifiers and eventually non-denitrifying $\mathrm{N}_{2} \mathrm{O}$ reducers to consume $\mathrm{N}_{2} \mathrm{O}$ under moderately acidic conditions. Those findings support the hypothesis that short-term water table fluctuations affect denitrifier activity rather than their community composition. It is feasible that enhanced overall denitrification rates as they can be expected under certain conditions (e.g., after prolonged flooding) and enhanced $\mathrm{N}_{2} \mathrm{O}$ consumption rates equal out, thus leading to rather stable overall $\mathrm{N}_{2} \mathrm{O}$ fluxes.

\section{AUTHOR CONTRIBUTIONS}

Conceived and designed the experiments: KP, JK, GG, and MH. Performed the experiments: KP and JK. Analyzed the data: KP, JK, GG, and MH. Contributed reagents/materials/analysis tools: $\mathrm{MH}$ and GG. Wrote the paper: $\mathrm{KP}$ and $\mathrm{MH}$.

\section{ACKNOWLEDGMENTS}

Funding for this work was provided by the Deutsche Forschungsgemeinschaft (DFG HO 4020/2-2 and GE 565/6-3) and the University of Bayreuth as part of the Research Unit 562 "Dynamics of soil processes under extreme meteorological boundary conditions" (FOR 562). The authors are thankful for support by Harold L. Drake and the collaborations with all partners of the DFG Research Unit "Soil processes" FOR 562.

\section{SUPPLEMENTARY MATERIAL}

The Supplementary Material for this article can be found online at: http://journal.frontiersin.org/article/10.3389/fmicb. 2016.00727

Figure S1 | Effect of artificial drought (2008) and prolonged flooding (2009) on watertables in control and treatment plots. Negative values indicate a watertable below the peat surface, positive values indicate a watertable above the peat surface. Averages of 18 piezometer measurements (6 per plot) are displayed. Error bars have been omitted to improve picture clarity. Sampling time points are indicated by vertical black lines.

Figure S2 | Effect of experimental drought (A-D) and prolonged flooding (E-H) on community composition of narG in DNA (A,B,E,F) and CDNA $(C, D, G, H)$ in fen soil from 0 to $20 \mathrm{~cm}(A, C, E, G)$ and 20 to $40 \mathrm{~cm}(B, D, F, H)$ depth. PCR products were digested with Cfol. Mean values of values from all plots of one plot type and soil depths $0-20$ or $20-40 \mathrm{~cm}$ (i.e., $3 \times 2=6$ ) are displayed. TRFs with a relative abundance $<5 \%$ in all samples are combined as "Rare." Pre-drought samples were taken on June 09th 2008, post-drought samples were taken on July 27th 2008. Pre-flooding samples were taken on May 11th 2009, post-flooding samples were taken on November 16th 2009. TRFLP patterns were dominated by TRFs of 23,57 , and 128 bp size, which were indicative of FEN CLUSTER 7 (Deinococcus-Thermus sp.-related uncultured soil bacteria), FEN CLUSTER 6 (Actinobacteria-related uncultured soil bacteria), and FEN CLUSTERS 1-5 (related to uncultured Proteobacteria).

Figure S3 | Effect of experimental drought (A-D) and prolonged flooding $(E-H)$ on community composition of nos $Z$ in DNA 


\section{$(A, B, E, F)$ and cDNA $(C, D, G, H)$ in fen soil from 0 to $20 \mathrm{~cm}$} $(A, C, E, G)$ and 20 to $40 \mathrm{~cm}(B, D, F, H)$ depth. PCR products were digested with Fnu4HI. Mean values of values from all plots of one plot type and soil depths $0-20$ or $20-40 \mathrm{~cm}$ (i.e., $3 \times 2=6$ ) are displayed. TRFs with a relative abundance $<5 \%$ in all samples are combined as "Rare." Pre-drought samples were taken on June 09th 2008, post-drought samples were taken on July 27th 2008. Pre-flooding samples were taken on May 11th 2009, post-flooding samples were taken on November 16th 2009. In DNA samples, the five most prominent TRFs $(149,165,215,298,700 \mathrm{bp})$ had cumulative relative abundances of $82-99 \%$ in all treaments and sampling time points in 2008 and 2009. In cDNA samples, those same TRFs accounted only for $22-52 \%$ and $38-90 \%$ of the TRFs in 2008 and 2009, respectively. The TRFs were indicative of FEN CLUSTER 1 (TRFs 165, 298; affiliated with Bradyrhizobiaceae-related uncultured soil bacteria) and FEN CLUSTERS 3-5 (TRFs 149, 215; affiliated with Rhodospirillaceae-related uncultured soil bacteria).

\section{REFERENCES}

Andert, J., Börjesson, G., and Hallin, S. (2012). Temporal changes in methane oxidizing and denitrifying communities and their activities in a drained peat soil. Wetlands 32, 1047-1055. doi: 10.1007/s13157-012-0335-3

Basiliko, N., Henry, K., Gupta, V., Moore, T. R., Driscoll, B. T., and Dunfield, P. F. (2013). Controls on bacterial and archaeal community structure and greenhouse gas production in natural, mined, and restored Canadian peatlands. Front. Microbiol. 4:215. doi: 10.3389/fmicb.2013.00215

Baumann, B., Snozzi, M., Zehnder, A. J. B., and Van Der Meer, R. J. (1996). Dynamics of denitrification activity of Paracoccus denitrificans in continuous culture during aerobic-anaerobic changes. J. Bacteriol. 178, 4367-4374.

Bremer, C., Braker, G., Matthies, D., Reuter, A., Engels, C., and Conrad, R. (2007). Impact of plant functional group, plant species, and sampling time on the composition of nirK-type denitrifier communities in soil. Appl. Environ. Microb. 73, 6876-6884. doi: 10.1128/AEM.01536-07

Caporaso, J. G., Kuczynski, J., Stombaugh, J., Bittinger, K., Bushman, F. D., Costello, E. K., et al. (2010). Qiime allows analysis of highthroughput community sequencing data. Nat. Methods 7, 335-336. doi: 10.1038/nmeth.f.303

Christensen, T. R., Ekberg, A., Strom, L., Mastepanov, M., Panikov, N., Oquist, M., et al. (2003). Factors controlling large scale variations in methane emissions from wetlands. Geophys. Res. Lett. 30, 1414. doi: 10.1029/2002GL016848

Conrad, R. (1996). Soil microorganisms as controllers of atmospheric trace gases $\left(\mathrm{H}_{2}, \mathrm{CO}, \mathrm{CH}_{4}, \mathrm{OCS}, \mathrm{N}_{2} \mathrm{O}\right.$, and NO). Microbiol. Rev. 60, 609-640.

da Costa, M. S., Rainey, F. A., and Nobre, M. F. (2006). "The genus Thermus and relatives," in The Prokaryotes. A Handbook on the Biology of Bacteria, 3rd Edn. eds M. Dworkin, S. Falkow, E. Rosenberg, K. H. Schleifer, and E. Stackebrandt (New York, NY: Springer), 797-812.

Davies, K. J. P., Lloyd, D., and Bobby, L. (1989). The effect of oxygen on denitrification in Paracoccus denttrificans and Pseudomonas aeruginosa. J. Gen. Microbiol. 135, 244-2451.

Dinsmore, K. J., Skiba, U. M., Billett, M. F., and Rees, R. M. (2009). Effect of water table on greenhouse gas emissions from peatland mesocosms. Plant Soil 318, 229-242. doi: 10.1007/s11104-008-9832-9

Dworkin, M., Falkow, S., Rosenberg, E., Schleifer, K.-H., and Stackebrandt, E. (2006). The Prokaryotes, Volume 5: Proteobacteria: Alpha and Beta Subclasses. New York, NY: Springer.

Egert, M., and Friedrich, M. W. (2003). Formation of pseudo-terminal restriction fragments, a PCR-related bias affecting terminal restriction fragment length polymorphism analysis of microbial community structure. Appl. Environ. Microb. 69, 2555-2562. doi: 10.1128/AEM.69.5.2555-2562.2003

Elberling, B., Askaer, L., Jørgensen, C. J., Joensen, H. P., Kuhl, M., Glud, R. N., et al. (2011). Linking soil $\mathrm{O}_{2}, \mathrm{CO}_{2}$, and $\mathrm{CH}_{4}$ concentrations in a wetland soil: implications for $\mathrm{CO}_{2}$ and $\mathrm{CH}_{4}$ fluxes. Environ. Sci. Tech. 45, 3393-3399. doi: $10.1021 / \mathrm{es} 103540 \mathrm{k}$

Estop-Aragonés, C., Knorr, K. H., and Blodau, C. (2012). Controls on in situ oxygen and dissolved inorganic carbon dynamics in peats of
Figure S4 | Effect of acetylene and supplemental nitrate on the production and consumption of $\mathrm{N}_{2} \mathrm{O}$ in anoxic microcosms with $0-20 \mathrm{~cm}(1)$ and 20-40 cm (2) fen soil. Blue squares represent the pre-flooding control plot, red circles represent the pre-flooding treatment plot, black triangles represent the post-flooding control plot, green diamonds represent the post-flooding treatment plot. Closed symbols represent microcosms with acetylene, open symbols represent microcosms without acetylene. Supplied concentrations of nitrate were $0 \mu \mathrm{M}$ (A), $10 \mu \mathrm{M}$ (B), $20 \mu \mathrm{M}$ (C), $40 \mu \mathrm{M}$ (D), and $100 \mu \mathrm{M}$ (E). Mean values and standard errors of three replicate microcosms are shown.

Figure S5 | Effect of prolonged flooding on apparent Michaelis-Menten kinetics in peat soil from 0 to $20 \mathrm{~cm}$ (A) and 20 to $\mathbf{4 0} \mathrm{cm}$ (B) peat soil. $\mathrm{N}_{2} \mathrm{O}$-production rates were measured at different nitrate concentrations in microcosms that were supplemented with acetylene. Averages of three measurements and standard errors are displayed. Open symbols $=$ control plots, closed symbols $=$ treatment plots. Squares $=$ pre-flooding, circles $=$ post-flooding.

a temperate fen. J. Geophys. Res. 117:G02002. doi: 10.1029/2011JG 001888

Estop-Aragonés, C., Knorr, K. H., and Blodau, C. (2013). Belowground in situ redox dynamics and methanogenesis recovery in a degraded fen during dry-wet cycles and flooding. Biogeosciences 10, 421-436. doi: 10.5194/bg-10-421-2013

Fromin, N., Pinay, G., Montuelle, B., Landais, D., Ourcival, J. M., Joffre, R., et al. (2010). Impact of seasonal sediment desiccation and rewetting on microbial processes involved in greenhouse gas emissions. Ecohydrology 3, 339-348. doi: 10.1002/eco. 115

Goldberg, S. D., Knorr, K. H., Blodau, C., Lischeid, G., and Gebauer, G. (2010). Impact of altering the water table height of an acidic fen on $\mathrm{N}_{2} \mathrm{O}$ and $\mathrm{NO}$ fluxes and soil concentrations. Glob. Change Biol. 16, 220-233. doi: 10.1111/j.13652486.2009.02015.x

Goldberg, S. D., Knorr, K. H., and Gebauer, G. (2008). $\mathrm{N}_{2} \mathrm{O}$ concentration and isotope signature along profiles provide deeper insight into the fate of $\mathrm{N}_{2} \mathrm{O}$ in soils. Isot. Environ. Health Stud. 44, 377-391. doi: 10.1080/10256010802507433

Gong, J. N., Wang, K. Y., Kellomäki, S., Zhang, C., Martikainen, P. J., and Spurpali, N. (2012). Modeling water table changes in boreal peatlands of Finland under changing climate conditions. Ecol. Model. 244, 65-78. doi: 10.1016/j.ecolmodel.2012.06.031

Gorham, E. (1991). Northern peatlands-role in the carbon-cycle and probable responses to climatic warming. Ecol. Appl. 1, 182-195. doi: 10.2307/1941811

Griffiths, B. S., and Philippot, L. (2013). Insight into the resistance and resilience of the soil microbial community. FEMS Microbiol. Rev. 37, 112-129. doi: 10.1111/j.1574-6976.2012.00343.x

Griffiths, R. I., Whiteley, A. S., O'Donnell, A. G., and Bailey, M. J. (2000). Rapid method for coextraction of DNA and RNA from natural environments for analysis of ribosomal DNA- and rRNA-based microbial community composition. Appl. Environ. Microb. 66, 5488-5491. doi: 10.1128/AEM.66.12.5488-5491.2000

Hartmann, D. L., Klein Tank, A. M. G., Rusticucci, M., Alexander, L. V., Brönnimann, S., Charabi, Y., et al. (2013). "Observations: atmosphere and surface," in Climate Change 2013: The Physical Science Basis. Contribution of Working Group I to the Fifth Assessment Report of the Intergovernmental Panel on Climate Change, eds T. F. Stocker, D. Qin, G. K. Plattner, M. Tignor, S. K. Allen, J. Boschung, A. Nauels, Y. Xia, V. Bex, and P. M. Midgley (Cambridge, UK; New York, NY: Cambridge University Press), 159-254.

Herrmann, M., Hädrich, A., and Küsel, K. (2012). Predominance of thaumarchaeal ammonia oxidizer abundance and transcriptional activity in an acidic fen. Environ. Microbiol. 14, 3013-3025. doi: 10.1111/j.1462-2920.2012.02882.X

Hu, Z., Meng, H., Shi, S.-H., Bu, N.-.S., Fang, C.-M., and Quan, Z.-X. (2014). Community size and composition of ammonia oxidizers and denitrifiers in an alluvial intertidal wetland ecosystem. Front. Microbiol. 5:371. doi: 10.3389/fmicb.2014.00371

Jones, C. M., Graf, D. R. H., Bru, D., Philippot, L., and Hallin, S. (2013). The unaccounted yet abundant nitrous oxide-reducing microbial community: a potential nitrous oxide sink. ISME J. 7, 417-426. doi: 10.1038/ismej. 2012.125 
Jørgensen, C. J., and Elberling, B. (2012). Effects of flooding-induced $\mathrm{N}_{2} \mathrm{O}$ production, consumption and emission dynamics on the annual $\mathrm{N}_{2} \mathrm{O}$ emission budget in wetland soil. Soil Biol. Biochem. 53, 9-17. doi: 10.1016/j.soilbio.2012.05.005

Kim, S. Y., Lee, S. H., Freeman, C., Fenner, N., and Kang, H. (2008). Comparative analysis of soil microbial communities and their responses to the short-term drought in bog, fen, and riperian wetlands. Soil Biol. Biochem. 40, 2874-2880. doi: 10.1016/j.soilbio.2008.08.004

Kolb, S., and Horn, M. A. (2012). Microbial $\mathrm{CH}_{4}$ and $\mathrm{N}_{2} \mathrm{O}$ consumption in acidic wetlands. Front. Microbiol. 3:78. doi: 10.3389/fmicb.2012.00078

Lipson, D. A., Zona, D., Raab, T. K., Bozzolo, F., Mauritz, M., and Oechel, W. C. (2012). Water-table height and microtopography control biogeochemical cycling in an Arctic coastal tundra ecosystem. Biogeosciences 9, 577-591. doi: 10.5194/bg-9-577-2012

Liu, J., Hou, H., Sheng, R., Chen, Z., Zhu, Y., Qin, H., et al. (2012). Denitrifying communities differentially respond to flooding drying cycles in paddy soils. Appl. Soil Ecol. 62, 155-162. doi: 10.1016/j.apsoil.2012.06.010

Lohila, A., Aurela, M., Hatakka, J., Pihlatie, M., Minkkinen, K., Penttilä, T., et al. (2010). Responses of $\mathrm{N}_{2} \mathrm{O}$ fluxes to temperature, water table and $\mathrm{N}$ deposition in a northern boreal fen. Eur. J. Soil Sci. 61, 651-661. doi: 10.1111/j.13652389.2010.01265.x

Maljanen, M., Sigurdsson, B. D., Guomundsson, J., Oskarsson, H., Huttunen, J. T., and Martikainen, P. J. (2010). Greenhouse gas balances of managed peatlands in the nordic countries - present knowledge and gaps. Biogeosciences 7, 2711-2738. doi: 10.5194/bg-7-2711-2010

Mander, U., Maddison, M., Soosaar, K., and Karabelnik, K. (2011). The impact of pulsing hydrology and fluctuating water table on greenhouse gas emissions from constructed wetlands. Wetlands 31, 1023-1032. doi: 10.1007/s13157-0110218-z

Marhan, S., Philippot, L., Bru, D., Rudolph, S., Franzaring, J., Högy, P., et al. (2011). Abundance and activity of nitrate reducers in an arable soil are more affected by temporal variation and soil depth than by elevated atmospheric $\left[\mathrm{CO}_{2}\right]$. FEMS Microbiol. Ecol. 76, 209-219. doi: 10.1111/j.1574-6941.2011.01048.x

Martikainen, P. J., Nykänen, H., Crill, P., and Silvola, J. (1993). Effect of a lowered water-table on nitrous-oxide fluxes from northern peatlands. Nature 366, 51-53. doi: $10.1038 / 366051 \mathrm{a} 0$

Marushchak, M., Pitkämäki, A., Koponen, H., Biasi, C., Seppälä, M., and Martikainen, P. (2011). Hot-spots for nitrous oxide emissions found in different types of permafrost peatlands. Glob. Change Biol. 17, 2601-2614. doi: 10.1111/j.1365-2486.2011.02442.x

McKenney, D. J., Drury, C. F., Findlay, W. I., Mutus, B., McDonnell, T., and Gajda, C. (1994). Kinetics of denitrification by Pseudomonas fluorescens: Oxygen effects. Soil Biol. Biochem. 26, 901-908. doi: 10.1016/0038-0717(94)90306-9

McKew, B. A., Taylor, J. D., McGenity, T. J., and Underwood, G. J. C. (2011). Resistance and resilience of benthic biofilm communities from a temperate saltmarsh to desiccation and rewetting. ISME J. 5, 30-41. doi: 10.1038/ismej.2010.91

McNicol, G., and Silver, W. L. (2014). Separate effects of flooding and anaerobiosis on soil greenhouse gas emissions and redox sensitive biogeochemistry. $J$. Geophys. Res. 119, 557-566. doi: 10.1002/2013JG002433

Mosier, A., Kroeze, C., Nevison, C., Oenema, O., Seitzinger, S., and van Cleemput, O. (1998). Closing the global N2O budget: nitrous oxide emissions through the agricultural nitrogen cycle - OECD/IPCC/IEA phase II development of IPCC guidelines for national greenhouse gas inventory methodology. Nutr. Cycl. Agroecosys. 52, 225-248. doi: 10.1023/A:1009740530221

Muyzer, G., De Waal, E. C., and Uitterlinden, A. G. (1993). Profiling of complex microbial populations by denaturing gradient gel electrophoresis analysis of polymerase chain reaction-amplified genes coding for 16S rRNA. Appl. Environ. Microb. 59, 695-700.

Novak, M., Gebauer, G., Thoma, M., Curik, J., Stepanova, M., Jackova, I., et al. (2015). Denitrification at two nitrogen-polluted, ombrotrophic Sphagnum bogs in Central Europe: insights from porewater $\mathrm{N}_{2} \mathrm{O}$-isotope profiles. Soil Biol. Biochem. 81, 48-57. doi: 10.1016/j.soilbio.2014.10.021

Orellana, L. H., Rodriguez-R., L. M., Higgins, S., Chee-Sanford, J. C., Sanford, R. A., Ritalahti, K. M., et al. (2014). Detecting nitrous oxide reductase (nos $Z$ ) genes in soil metagenomes: method development and implications for the nitrogen cycle. mBio 5, e01193-14. doi: 10.1128/mBio.01193-14
Palmer, K., Biasi, C., and Horn, M. A. (2012). Contrasting denitrifier communities relate to contrasting $\mathrm{N}_{2} \mathrm{O}$ emission patterns from acidic peat soils in arctic tundra. ISME J. 6, 1058-1077. doi: 10.1038/ismej.2011.172

Palmer, K., Drake, H. L., and Horn, M. A. (2010). Association of novel and highly diverse acid-tolerant denitrifiers with $\mathrm{N}_{2} \mathrm{O}$ fluxes of an acidic fen. Appl. Environ. Microb. 76, 1125-1134. doi: 10.1128/AEM.02256-09

Palmer, K., and Horn, M. A. (2012). Actinobacterial nitrate reducers and Proteobacterial denitrifiers are abundant in $\mathrm{N}_{2} \mathrm{O}$-metabolizing palsa peat. Appl. Environ. Microb. 78, 5584-5596. doi: 10.1128/AEM.00810-12

Palmer, K., and Horn, M. A. (2015). Denitrification activity of a remarkably diverse fen denitrifier community in Finnish Lapland is N-oxide limited. PLoS ONE 10:e0123123. doi: 10.1371/journal.pone.0123123

Persoh, D., Theuerl, S., Buscot, F., and Rambold, G. (2008). Towards a universally adaptable method for quantitative extraction of high-purity nucleic acids from soil. J. Microbiol. Methods 75, 19-24. doi: 10.1016/j.mimet.2008.04.009

Pett-Ridge, J., and Firestone, M. (2005). Redox fluctuations structures microbial communities. Appl. Environ. Microbiol. 71, 6998-7007. doi: 10.1128/AEM.71.11.6998-7007.2005

Philippot, L., Piutti, S., Martin-Laurent, F., Hallet, S., and Germon, J. C. (2002). Molecular analysis of the nitrate-reducing community from unplanted and maize-planted soils. Appl. Environ. Microb. 68, 6121-6128. doi: 10.1128/AEM.68.12.6121-6128.2002

Ravishankara, A. R., Daniel, J. S., and Portmann, R. W. (2009). Nitrous oxide $\left(\mathrm{N}_{2} \mathrm{O}\right)$ : the dominant ozone-depleting substance emitted in the 21st century. Science 326, 123-125. doi: 10.1126/science.1176985

Reiche, M., Hädrich, A., Lischeid, G., and Küsel, K. (2009). Impact of manipulated drought and heavy rainfall events on peat mineralization processes and source-sink functions of an acidic fen. J. Geophys. Res. 114:G02021. doi: 10.1029/2008JG000853

Rich, J. J., Heichen, R. S., Bottomley, P. J., Cromack, K., and Myrold, D. D. (2003). Community composition and functioning of denitrifying bacteria from adjacent meadow and forest soils. Appl. Environ. Microb. 69, 5974-5982. doi: 10.1128/AEM.69.10.5974-5982.2003

Royer-Tardif, S., Bradley, R. L., and Parsons, W. F. J. (2010). Evidence that plant diversity and site productivity confer stability to forest floor microbial biomass. Soil Biol. Biochem. 42, 813-821. doi: 10.1016/j.soilbio.2010.01.018

Russow, R., Tauchnitz, N., Spott, O., Mothes, S., Bernsdorf, S., and Meissner, R. (2013). Nitrate turnover in a peat soil under drained and rewetted conditions: results from a $[15 \mathrm{~N}]$ nitrate-bromide double-tracer study: dedicated to professor Dr habil. Hans Faust on the occasion of his 85th birthday. Isot. Environ. Healt. Stud. 49, 438-453. doi: 10.1080/10256016.2013. 831089

Saarenheimo, J., Tiirola, M. A., and Rissanen, A. J. (2015). Functional gene pyrosequencing reveals core proteobacterial denitrifiers in boreal lakes. Front. Microbiol. 6:674. doi: 10.3389/fmicb.2015.00674

Shapleigh, J. (2013). "Denitrifying prokaryotes," in The Prokaryotes, eds E. Rosenberg, E. Delong, S. Lory, E. Stackebrandt, and F. Thompson (Heidelberg: Springer), 405-425.

Silvola, J., Alm, J., Ahlholm, U., Nykänen, H., and Martikainen, P. J. (1996). $\mathrm{CO}_{2}$ fluxes from peat in boreal mires under varying temperature and moisture conditions. J. Ecol. 84, 219-228. doi: 10.2307/2261357

Song, K., Lee, S. H., Mitsch, W. J., and Kang, H. (2010). Different responses of denitrification rates and denitrifying bacterial communities to hydrological pulsing in created wetlands. Soil Biol. Biochem 42, 1721-1727. doi: 10.1016/j.soilbio.2010.06.007

Stres, B., Danevcic, T., Pal, L., Fuka, M. M., Resman, L., Leskovec, S., et al. (2008). Influence of temperature and soil water content on bacterial, archaeal and denitrifying microbial communities in drained fen grassland soil microcosms. FEMS Microbiol. Ecol. 66, 110-122. doi: 10.1111/j.1574-6941.2008.00555.x

Tauchnitz, N., Spott, O., Russow, R., Bernsdorf, S., Glaser, B., and Meissner, R. (2015). Release of nitrous oxide and dinitrogen from a transition bog under drained and rewetted conditions due to denitrification: results from a [15N]nitrate-bromide double-tracer study. Isot. Environ. Healt. Stud. 51, 300-321. doi: 10.1080/10256016.2015.1011634

Theodorakopoulos, N., Bachar, D., Christen, R., Alain, K., and Chapon, V. (2013). Exploration of Deinococcus-Thermus molecular diversity by novel groupspecific PCR primers. MicrobiologyOpen 2, 862-872. doi: 10.1002/mbo3.119 
Tiedje, J. M., Sexstone, A. J., Myrold, D. D., and Robinson, J. A. (1982). Denitrification: ecological niches, competition and survival. Anton. Leeuw. 48, 569-583. doi: 10.1007/BF00399542

Vollack, K.-U., and Zumft, W. G. (2001). Nitric oxide signaling and transcriptional control of denitrification genes in Pseudomonas stutzeri. J. Bacteriol. 183, 2516-2526. doi: 10.1128/JB.183.8.2516-2526.2001

Wang, H., Yang, S.-H., Yang, J.-P., LV, Y.-M., Zhao, X., and Pang, J.-L. (2014). Temporal changes in soil bacterial and archaeal communities with different fertilizers in tea orchards. J. Zhejiang Univ. Sci. B 15, 953-965. doi: 10.1631/jzus.B1400114

Wüst, P. K., Horn, M. A., and Drake, H. L. (2009). Trophic links between fermenters and methanogens in a moderately acidic fen soil. Environ. Microbiol. 11, 1395-1409. doi: 10.1111/j.1462-2920.2009.01867.x

Yang, J. S., Liu, J. S., Hu, X. J., Li, X. X., Wang, Y., and Li, H. Y. (2013). Effect of water table level on $\mathrm{CO}_{2}, \mathrm{CH}_{4}$ and $\mathrm{N}_{2} \mathrm{O}$ emissions in a freshwater marsh of Northeast China. Soil Biol. Biochem. 61, 52-60. doi: 10.1016/j.soilbio.2013.02.009

Yoshinari, T., and Knowles, R. (1976). Acetylene inhibition of nitrous oxide reduction by denitrifying bacteria. Biochem. Biophys. Res. Commun. 69, 705-710. doi: 10.1016/0006-291X(76)90932-3
Zaprasis, A., Liu, Y. J., Liu, S. J., Drake, H. L., and Horn, M. A. (2010). Abundance of novel and diverse $t f d A$-like genes, encoding putative phenoxyalkanoic acid herbicide-degrading dioxygenases, in soil. Appl. Environ. Microb. 76, 119-128. doi: 10.1128/AEM.01727-09

Zenova, G. M., Manucharova, N. A., and Zvyagintsev, D. G. (2011). Extremophilic and extremotolerant actinomycetes in different soil types. Eurasian Soil Sci. 44, 417-436. doi: 10.1134/S1064229311040132

Zumft, W. G. (1997). Cell biology and molecular basis of denitrification. Microbiol. Mol. Biol. Rev. 61, 533-615.

Conflict of Interest Statement: The authors declare that the research was conducted in the absence of any commercial or financial relationships that could be construed as a potential conflict of interest.

Copyright (c) 2016 Palmer, Köpp, Gebauer and Horn. This is an open-access article distributed under the terms of the Creative Commons Attribution License (CC BY). The use, distribution or reproduction in other forums is permitted, provided the original author(s) or licensor are credited and that the original publication in this journal is cited, in accordance with accepted academic practice. No use, distribution or reproduction is permitted which does not comply with these terms. 